\author{
ks. Józef Warzeszak \\ Papieski Wydziat Teologiczny w Warszawie \\ ORCID: 0000-0002-2301-817X
}

\title{
Uniwersalno-teologalny wymiar muzyki i śpiewu w ujęciu Benedykta XVI
}

\section{Wprowadzenie}

Dlaczego muzyka ma wymiar uniwersalny? Ponieważ jej charakter jest powszechny, ponieważ jest sztuką ponadczasową, ponadnarodową, ponadkulturową, a nawet ponad kontynentalną. Ale dlaczego ma zarazem wymiar teologalny? Ponieważ nie zasklepia się jedynie w sobie, ale odznacza się zdolnością odsyłania poza siebie samą i prowadzi ku temu, co transcendentne i nieprzemijalne, bo wypływając z duszy artystycznie utalentowanej i religijnej, ukierunkowuje słuchacza na Boga. Dlatego można by w sumie mówić o jej wymiarze uniwersalno-teologalnym. W ujęciu Benedykta XVI te dwie sprawy bowiem bardzo ściśle się ze sobą łączą. Toteż podkreślając uniwersalny charakter muzyki, zwykle Benedykt akcentował również jej wymiar teologalny. Oba wątki: uniwersalny i teologalny pojawiały się u niego właściwie zawsze razem.

Mogłoby przy tym zastanawiać: dlaczego Benedykt w każdym pokoncertowym komentarzu kierował uwagę słuchaczy i muzyków ku Bogu? Czy tylko dlatego, że jako papieżowi wypadało mu to po prostu czynić? Zapewne, głosił w ten sposób wiarę w Boga Trójjedynego i w ogóle prawdy wiary. Ale - jak się wydaje - nie był to powód jedyny. Można bowiem przypuszczać, że papież czynił to także ze względu na audytorium, ponieważ chciał, by uwaga słuchaczy nie zatrzymywała się na muzyce jako takiej, tj. na jej pięknie estetycznym, ale by muzyka wyprowadzała ich dalej i wyżej, poza samo piękno, by zwracali uwagę na jej głębszy sens. Niewątpliwie czynił to także ze względu na wykonawców. Zapewne nie wszyscy muzycy czy chórzyści byli ludźmi wierzącymi. Chodziło mu więc o to, by i oni nie zatrzymywali się jedynie na estetycznym pięknie wykonywanych utworów muzycznych, ale by dostrzegali zarazem religijny sens swojej pracy; by dzieła kompozytora, które wykonywali, prowadziły ich ku Transcendencji. Zapewne czynił to także dlatego, by oddać sprawiedliwość samemu kompozytorowi, którego do stworzenia takiego, 
a nie innego dzieła muzycznego inspirowały często motywy religijne i który w języku muzycznym wyrażał po prostu swoją wiarę.

Twórczość teologiczno-muzykologiczna Josepha Ratzingera jest dobrze znana polskim teologom i muzykologom i jest bardzo przez nich ceniona. Wydano jego dzieła z tego zakresu: Opera omnia oraz inne ${ }^{1}$. O wielkości jego dorobku w tym zakresie i o dobrej znajomości jego dzieł świadczyć może fakt, że Uniwersytet Jana Pawła II w Krakowie nadał Benedyktowi XVI, kiedy został już papieżem - emerytem, doktorat honoris causa za zasługi w tej dziedzinie ${ }^{2}$. W „Pro Musica Sacra”, a także w innych czasopismach, opublikowano nawet kilka artykułów poświęconych jego myśli. Z tych wszystkich jego dzieł i opracowań wynika, że jako kardynał brał udział w dyskusjach na temat kształtowania się koncepcji muzyki i śpiewu liturgicznego po Soborze Watykańskim II, że jest doskonałym znawcą tej dziedziny twórczości. Ma duże zasługi.

Można zapytać: skoro został opracowany dorobek Josepha Ratzingera w zakresie muzykologii, to co nowego może wnieść niniejszy artykuł? Publikacje, do których udało mi się dotrzeć, skupiają się na jego dziełach sprzed powołania go na stolicę Piotrową, a tylko sporadycznie sięgają do jego wypowiedzi papieskich, i to raczej zawartych w jego urzędowych dokumentach, jak w tym o Eucharystii. Natomiast w niniejszym artykule przedmiotem analiz są przemówienia wygłoszone przez Benedykta XVI z okazji ofiarowanych mu koncertów, głównie przez muzyków z Niemiec i Włoch, a także w czasie spotkań z instytutami muzykologicznymi. Jest ich wszystkich ponad czterdzieści. Korzystałem z tych, które są umieszczone na stronie watykańskiej pod hasłem discorsi, a które łatwo odnaleźć po dacie podanej w przypisie. Wiele z nich opublikowano także w języku polskim w „L'Osservatore Romano”.

Wykonawcami koncertów były zwykle orkiestry symfoniczne, chóry oraz soliści. Benedykt dziękował za wszystkie: organizatorom, wykonawcom i uczestnikom. Zawsze wyrażał przy tym wdzięczność za dar żywej muzyki tak dla niego, jak i dla zebranej publiczności, która też była publicznością wytrawną. Podkreślał zazwyczaj, że dany koncert przyniósł mu wielką radość, głębokie przeżycia emocjonalne, duchowe, estetyczne, że piękno tej muzyki i śpiewu porwało jego ducha ku wielkim doznaniom, ku pięknu, a za pośrednictwem tego piękna ku Transcendencji, Prawdzie, ku Bogu, ale też ku wspólnocie świętych, że był to przedsmak niebiańskiego śpiewu aniołów i świętych.

1 Zob. J. Ratzinger, Teologia liturgii, tł. W. Szymona, red. K. Góźdź, Lublin 2012, s. 469-574 (Opera Omnia, 11).

2 Por. R. Tyrała, Benedykt XVI doktorem "honoris causa” Akademii Muzycznej i Uniwersytetu Papieskiego Jana Pawta II w Krakowie, „Pro Musica Sacra” 13 (2015), s. 9-37. 
Każdy z tych koncertów papież nazywał: „muzykalnym podarunkiem - przepięknym darem urodzinowym”, „darem przez wszystkich cenionym”, „ważnym wydarzeniem muzycznym” “ albo „chwilami o najwyższej wartości kulturalnej, bądź aktem szacunku i życzliwości, czy wyrazem wielkiego afektu, jaki lud włoski żywi dla papieża"s. Znajdował zawsze słowa wyrażające wysoką ocenę dyrygenta i orkiestry czy chóru. Na przykład o dyrygencie orkiestry Filharmonii w Monachium powiedział, że jego „mistrzostwo muzyczne staje się zawsze źródłem nowego entuzjazmu" ${ }^{6}$.

W niniejszym artykule będę starał się ukazać, jak Benedykt XVI jako papież wyrażał całą swą wiedzę teologiczno-muzykologiczną także w przemówieniach papieskich, jak ją wykorzystywał. Oczywiście znawcy muzykologii nie powinni się chyba spodziewać, że znajdą tu coś, czego przedtem zupełnie nie znali, czy z czym w ogóle się nie zetknęli. Niemniej jednak warto nakreślić obraz jego wiedzy w tej dziedzinie, jaki wyrażał, przejawiał, a nawet podkreślał w swych przemówieniach. Do tej wiedzy warto niewątpliwie powracać i wciąż na nowo ją ukazywać, gdyż wydaje się ona bardzo cenna, o czym - mam nadzieję - czytelnik będzie mógł się przekonać dzięki lekturze niniejszego artykułu.

\section{Wielka muzyka przedmiotem zainteresowań Benedykta XVI}

\subsection{Osobista więź Josepha Ratzingera - Benedykta XVI z muzyką i śpiewem}

Benedykt XVI wspomina, że kiedyś, jeszcze w czasie wojny, wybrał się ze swym bratem Georgiem na koncert utworów Mozarta do Salzburga. Świadczyć to może o tym, że już będąc małym chłopcem, uczył się doceniać wielkie dzieła muzyczne. W wywiadzie z okazji swoich 93. urodzin przyznał nawet, że miał kiedyś wspaniały głos, ale w ostatnim czasie niestety go utracił.

Był dumny i wdzięczny, że w nieprzerwanej stuletniej tradycji Regensburger Domspatzen jego brat Georg miał swój udział przez lat trzydzieści, a po zakończeniu tam pracy powiedział: „Dobry Bóg nie mógł mi powierzyć żadnego lepszego

3 Przemówienie po koncercie Orkiestry Symfonicznej Radia i Telewizji w Stuttgarcie ku czci papieża z okazji jego 80. urodzin, Aula Pawła VI, 16.04.2007.

4 Przemówienie na zakończenie koncertu wykonanego ku czci Benedykta XVI przez orkiestrę Filharmonii z Monachium w Bawarii, Aula Pawła VI, 20.10.2005.

5 Przemówienie po koncercie ofiarowanym przez prezydenta Republiki Włoskiej Giorgia Napolitana ku czci papieża z okazji 3. rocznicy jego pontyfikatu, Aula Pawła VI, 24.04.2008.

6 Przemówienie na zakończenie koncertu wykonanego ku czci Benedykta XVI przez orkiestrę Filharmonii z Monachium w Bawarii, Aula Pawła VI, 20.10.2005. 
zadania"7. I dodał, że dzięki koncertowi tego chóru, sam poczuł się przeniesiony w tamte piękne czasy, do Regensburga, gdy dzięki swemu bratu wrastał w rodzinę Domspatzen.

Po koncercie ofiarowanym przez Badenię-Wirtembergię ${ }^{8}$ papież wyznał, że patrząc wstecz na swoje życie, dziękuje Bogu, iż dał mu do towarzystwa muzykę, która stała się jakby towarzyszką w jego ziemskiej podróży; towarzyszką, która zawsze podtrzymywała i podtrzymuje go na duchu i pomnaża jego radość. Dziękował także tym, którzy od jego wczesnych, dziecięcych lat zbliżali go do tego źródła inspiracji i pogody ducha. Dziękował zarazem tym, którzy łączą muzykę z modlitwą w harmonijnym uwielbieniu Boga i Jego dzieł, i tym samym pomagają oddawać cześć Stwórcy - Odkupicielowi świata, świata, który jest cudownym dziełem Jego rąk.

W przemówieniu po koncercie muzyki Wolfganga Amadeusza Mozarta zorganizowanym przez Papieską Akademię Nauk w Castel Gandolfo ${ }^{9}$ Benedykt XVI wyznał, że do tego wspaniałego muzyka ma szczególny sentyment. Ilekroć bowiem słucha jego muzyki - to powraca pamięcią do lat dziecinnych, kiedy w jego kościele parafialnym, w dni świąteczne rozbrzmiewała właśnie Msza Mozarta. Czuł wtedy w sercu, że dociera do niego jakby promień niebiańskiego piękna i tego uczucia doznaje zawsze, kiedy słucha jego wielkiej, zarazem pełnej dramatyzmu i pogody ducha medytacji o śmierci. Potwierdził to papież emeryt - przy innej okazji - w podziękowaniu za nadanie mu doktoratu honoris causa w słowach: „Na trwałe (...) wpisało się w moją pamięć, że skoro tylko zabrzmiały pierwsze nuty Mszy koronacyjnej Mozarta, to jakby otwierało się niebo i można było bardzo głęboko odczuć obecność Pana"10. A jak pisze Robert Tyrała, po zagraniu - w czasie uroczystości wręczenia dyplomu - przez kwartet smyczkowy YPSYLON Akademii Muzycznej w Krakowie fragmentów dzieł Mozarta, „mogło się wydawać, że ta muzyka sprawiła laureatowi najwięcej radości”" ${ }^{11}$.

Po wspomnianym wyżej koncercie w Castel Gandolfo Benedykt XVI wyznał również, że jego podziw dla Mozarta pochodzi stąd, iż w jego dziełach panuje doskonała harmonia, że „wszystko, każda nuta, każda fraza muzyczna jest taka, jaka powinna być, nie inna”. Nawet przeciwieństwa wydają się tu ze sobą w jakiś

7 Przemówienie na zakończenie koncertu wykonanego ku czci papieża przez Regensburger Domspatzen - chór katedry w Ratyzbonie, Kaplica Sykstyńska, 22.10.2005.

8 Zob. Przemówienie po koncercie Orkiestry Symfonicznej Radia i Telewizji w Stuttgarcie ku czci papieża z okazji jego 80. urodzin, Aula Pawła VI, 16.04.2007.

9 Przemówienie po koncercie na dziedzińcu Pałacu Apostolskiego w Castel Gandolfo, 7.09.2010, L'Osservatore Romano" (wydanie polskie) [dalej: L'OR] 10 (2010), s. 27.

10 Cyt. za R. Tyrała, Benedykt XVI doktorem „honoris causa”..., dz. cyt., s. 25.

11 R. Tyrała, Benedykt XVI doktorem „honoris causa”..., dz. cyt., s. 23. 
sposób pogodzone, „a wszystko w każdym momencie spowija mozartische Heiterkeit-mozartowska pogoda”. Jest to z pewnością szczególnym darem Bożej łaski, lecz zarazem owocem „żywej wiary Mozarta, który - zwłaszcza w muzyce sakralnej - umiał ukazać pełną światła odpowiedź Bożej miłości, dającą nadzieję także wtedy, gdy w życie człowieka wdziera się cierpienie i śmierć” ${ }^{12}$.

Zacytował nawet list, który Mozart napisał 4 kwietnia 1787 roku do swego umierającego ojca, gdzie mówi o ostatnim etapie ziemskiego życia w sposób następujący: „Już od kilku lat tak bardzo zżyłem się z tą szczerą i drogą przyjaciółką człowieka (tj. ze śmiercia), że nie tylko jej obraz wcale mnie nie przeraża, leczy wydaje mi się wręcz uspokajający i pocieszający! Uważam to za swój wielki przywilej i dziękuję Bogu mojemu, który pozwolił mi zrozumieć, że śmierć jest kluczem do prawdziwej szczęśliwości. Zawsze, kiedy kładę się do łóżka, myślę, że nazajutrz może już mnie nie będzie. A przecież nikt z tych, którzy mnie znają, nie mógłby powiedzieć, że w towarzystwie jestem smutny lub okazuję zły humor. I za to szczęście dziękuję każdego dnia mojemu Stwórcy i życzę tego szczęścia z całego serca każdemu z moich bliźnich”.

List ten ukazuje jego wiarę - bogatą i prostą, odzwierciedloną w wielkiej modlitwie Requiem. „Każe nam ona głęboko kochać ziemskie życie, jako dar Boga, oraz wznosić się ponad nie, pogodnie wyglądając śmierci, niczym «klucza» do drzwi, przez które trzeba przejść, by dostąpić wiecznej szczęśliwości. Requiem Mozarta doskonale wyraża podobną wiarę, która dobrze zna tragizm ludzkiej egzystencji i nie przemilcza jej dramatycznych aspektów, wyraża więc wiarę prawdziwie chrześcijańską, świadomą, że całe życie człowieka oświeca Boża miłość”.

W czasie jednej z audiencji ${ }^{13}$ papież podzielił się osobistym przeżyciem koncertu muzyki Johanna Sebastiana Bacha w Monachium, kiedy to po zakończeniu ostatniej kantaty poczuł nie na drodze jakiegoś szczególnego rozumowania, lecz jakby w głębi serca, że to, co usłyszał, odkrywa przed nim niezwykłą prawdę, prawdę o najwyższym Kompozytorze - Bogu, co skłoniło go do tego, by $\mathrm{Mu}$ za to podziękować. Do siedzącego wówczas obok biskupa luterańskiego Benedykt XVI zwrócił się spontanicznie, mówiąc, że gdy słuchamy Bacha, ogarnia nas jasna pewność. Bo prawda staje się bardzo prawdziwa - tak silna i tak piękna, że wyraża nieodpartą obecność Boskiej prawdy. Nic przeto dziwnego, że każdy koncert wykonywany przez znakomitych muzyków robił na nim tak duże wrażenie. Zapadał mu głęboko w serce i jeszcze po wykonaniu długo brzmiał w jego wnętrzu.

12 Przemówienie po koncercie na dziedzińcu Pałacu Apostolskiego w Castel Gandolfo, 7.09.2010, L'OR 10 (2010), s. 27.

13 Por. Katecheza w czasie audiencji generalnej, Castel Gandolfo, 31.08.2011. 


\subsection{Czym jest $\mathrm{i}$ czym nie jest muzyka?}

W jednym z przemówień wygłoszonych po koncercie muzyki wokalnej i instrumentalnej, papież podjął nawet refleksję nad samą istotą muzyki jako takiej ${ }^{14}$. Zaczął od tego, że muzyka nie jest zwykłym ciągiem następujących po sobie dźwięków, ale że ma też swoisty rytm, a zarazem spoistość oraz harmonię; posiada też pewną strukturę i głębię. Podkreślił, że tego wszystkiego w sposób niezwykły pozwolili właśnie zakosztować swym wielogłosowym śpiewem chóralnym, który wybrzmiewał z niezwykłą mocą i ekspresją, chórzyści z grupy Cantico, ale także muzycy wykonujący niezwykłe utwory instrumentalne. Wykonawcy porwali wprost słuchaczy ciepłymi dźwiękami i wielką pełnią gry na wiolonczeli. Stało się tak, ponieważ muzyka jest wyrazem ducha, wyrazem wewnętrznej przestrzeni osoby, stworzonej do wszystkiego, co prawdziwe, dobre i piękne. Nie przez przypadek muzyka często towarzyszy modlitwie wiernych. Wzbudza bowiem uczucia i zarazem porusza duszę, kiedy ta dusza spotyka się na modlitwie z Bogiem.

W związku z tym papież zacytował fragment hymnu poświęconego św. Klarze, której wspomnienie Kościół obchodził akurat w dniu koncertu. Powiedziano tam o niej: „Z jasności Boga otrzymałaś światło. Ty dałaś Mu miejsce, gdzie to światło wzrosło i rozprzestrzeniło się w świecie i rozjaśnia nasze serca”. Dalej zauważył, że jest to fundamentalna postawa człowieka, która ogarnia całe jego jestestwo i zapewnia mu pokój, tj.: otwarcie na jasność (claritas) Boga, jaśniejące piękno i siłę życiową Stwórcy, który ożywia i pozwala człowiekowi wyrastać ponad samego siebie. Wykonawcy koncertu wyróżnili się przy tym wielką kreatywnością muzyczną, szerokością i rozległością harmonii i w ten sposób przyczynili się do tego, iż owa claritas Dei oświeciła również słuchaczy. Wyraził na koniec życzenie, by artyści biorąc za punkt wyjścia swe głębokie doświadczenie piękna - zaangażowali się również na rzecz dobra i ofiarowali swą pomoc, podtrzymując na duchu potrzebujących. By przekazywali innym dobro, które sami otrzymali w darze, żeby rozprzestrzeniało się w świecie. W ten bowiem sposób wzrasta każdy ludzki byt, stając się coraz bardziej przejrzystym i świadomym obecności oraz działania swego Stwórcy.

\subsection{Znawca muzyki i śpiewu}

Z przemówień Benedykta XVI wynika bardzo jasno, iż posiada on doskonałą znajomość twórczości muzycznej. Przedstawiał zwykle kontekst, w jakim powstawało dane dzieło; wiedział, co chciał w nim wyrazić kompozytor. Widać, że umiał

\footnotetext{
14 Por. Przemówienie po koncercie ofiarowanym przez Caritas z Regensburga, Castel Gandolfo, 11.08.2012.
} 
z pełnym zrozumieniem słuchać wielkich utworów, że potrafił odczytywać intencje kompozytora i wykonawców, że umiał też wychwycić, co zamierzał wyakcentować dyrygent z orkiestrą i chórem. Potrafił przy tym odczytywać najmniejsze niuanse, a zarazem głęboko przeżywać tę muzykę; trafiała ona do jego wnętrza, wywierała na nim nie tylko głębokie wrażenie i powodowała emocje, ale wywoływała wprost wielkie przeżycia duchowe. Dzięki temu muzyka przynosiła mu pociechę, podnosiła go na duchu, ożywiała jego codzienność i nadawała świąteczny i wzniosły charakter powszedniości dnia powszedniego.

Autor wprowadzenia do przemówienia Benedykta XVI na zakończenie koncertu Orkiestry Symfonicznej i Chóru Radia Bawarskiego pisze, że papież wypowiadał się wówczas jako muzyk i teolog ${ }^{15}$. Kiedy czyta się dziś papieskie przemówienia pokoncertowe, ciśnie się na usta określenie: muzykolog i teolog. Benedykt XVI powiedział wtedy, że sprawiono mu oryginalny prezent w postaci niezwykłego wydarzenia muzycznego, dzięki znakomitym solistom, wybitnemu dyrygentowi, jak również dzięki porywającej interpretacji IX Symfonii Beethovena. Symfonię tę określił jako imponujące arcydzieło należące do uniwersalnego dziedzictwa ludzkości i wciąż wzbudzające jego zachwyt.

Przypomniał też, że powstaniu tego dzieła towarzyszyły wyjątkowe okoliczności: Otóż „po latach izolacji i samotniczego życia, podczas, których Beethoven musiał zmagać się z trudnościami wewnętrznymi i zewnętrznymi, które pogrążały go w depresji i rozgoryczały, zagrażając jego twórczości artystycznej, w 1824 r., zupełnie już głuchy, kompozytor zadziwia publiczność utworem, który łamie tradycyjne ramy symfonii i zostaje uwieńczony nadzwyczajnym finałem wyrażającym optymizm i radość". Podkreślił równocześnie, że to przemożne uczucie radości, przetransponowane w muzykę, nie jest ani błahe, ani powierzchowne. Beethoven, jako człowiek, którego głuchota skazała na kompletną izolację, odzyskał bowiem to uczucie radości kosztem wielkiego wysiłku, by przezwyciężyć tę zagrażającą mu wewnętrzną pustkę. Muzycznie wyrażają to puste kwinty w pierwszej części utworu i wielokrotnie powracający posępny nastrój. Tak więc „pełna ciszy samotność nauczyła Beethovena nowego sposobu słuchania, znacznie doskonalszego od zwykłej zdolności «słyszenia» w wyobraźni brzmienia czytanych lub zapisywanych nut".

I dalej papież wyjaśnił to od strony teologicznej, wskazując, że sytuację kompozytora mogą ilustrować słowa Iz 29, 18-24: „W ów dzień głusi usłyszą słowa księgi (czyli słowa jedynie zapisane), a oczy niewidomych, wolne od mroku i od ciemności, będą widzieć". Autor natchniony wskazuje tu na szczególną zdolność postrzegania, jaką zostaje obdarowany ten, kto od Boga otrzymuje łaskę zewnętrznego

15 Zob. Przemówienie po koncercie Orkiestry Symfonicznej i Chóru Radia Bawarskiego, Aula Pawła VI, 27.10.2007, L'OR 12 (2007), s. 21. 
i wewnętrznego wyzwolenia. „Źródłem prawdziwej radości jest wolność, którą ostatecznie może obdarzyć jedynie Bóg. On - niekiedy właśnie przez okresy wewnętrznej pustki i izolacji - chce nas uwrażliwić na swoją milczącą obecność nie tylko "ponad rozgwieżdżonym firmamentem», lecz także w głębi naszej duszy. Tam właśnie świeci iskra Bożej miłości, która może nas wyzwolić do tego, czym naprawdę jesteśmy" ${ }^{16}$.

Koncert ofiarowany z okazji IV rocznicy pontyfikatu przez prezydenta Włoch Giorgia Napolitana Benedykt XVI określił jako wspaniałe homagium muzyczne ${ }^{17}$, które wykonały orkiestra i chór imienia Giuseppe Verdiego z Mediolanu, dając nowe życie wybranym fragmentom dzieł autorów pierwszej wielkości, jakimi byli: Vivaldi, Haydn i Mozart, a które zostały dopasowane do trwającego wtedy okresu paschalnego, czyli przejścia od śmierci do zmartwychwstania. Ten charakter nadała koncertowi zwłaszcza Symfonia 95. Haydna, wykonana na samym początku. I rzeczywiście, „Koncert rozpoczął się od tonacji d-moll, następnie przebiegał coraz doskonalej zrównoważony, choć nie pozbawiony dramaturgii, by przy końcu dojść do D-dur. Każe to myśleć o drodze duszy - przedstawionej zwłaszcza przez wiolonczelę - prowadzącej ku pokojowi i pogodzie ducha. Następująca po tym Symfonia 35. Mozarta osiągnęła niemal rangę wzmocnienia i była ukoronowaniem potwierdzenia dominacji życia nad śmiercią, radości nad smutkiem. W tej symfonii zdecydowanie przeważa poczucie święta. Przebieg wykonania jest bardzo dynamiczny, a w zakończeniu wprost rozpędzony. I tu wykonawcy - wirtuozi z orkiestry pozwolili uzmysłowić słuchaczom, jaka siła może łączyć się z łaską. To zaś dokonuje się w najwyższym stopniu w miłości Boga, w której utożsamiają się wszechmoc i łaska”.

Potem wyszły na scenę głosy ludzkie - chórzyści - by niejako ubrać w słowa to, co wcześniej muzyka chciała wyrazić. „Nie przypadkiem pierwszym słowem było Magnificat - słowo, które wyszło z serca Maryi, umiłowanej przez Boga ze względu na swą pokorę. Jej słowo stało się codziennym śpiewem Kościoła w czasie nieszporów, w godzinie, która zachęca do medytacji nad sensem życia i historii. Oczywiście Magnificat zakłada również zmartwychwstanie, czyli zwycięstwo Chrystusa nad śmiercią. W nim Bóg urzeczywistnił swe obietnice i Jego miłosierdzie objawiło się w całej swej paradoksalnej mocy”. Mówiło o tym słowo śpiewane.

Po tym nastąpiło wykonanie muzyki Vivaldiego. Papież zaś zwrócił uwagę na fakt, że Vivaldi skomponował arie solowe dla swych pięciu wychowanek

16 Przemówienie po koncercie wykonanym przez Orkiestrę Symfoniczną i Chór Radia Bawarskiego, dz. cyt., s. 22.

17 Zob. Przemówienie po koncercie ofiarowanym przez prezydenta Republiki Włoskiej Giorgia Napolitana z okazji 4. rocznicy pontyfikatu papieża, 30.04.2009. 
w weneckim sierocińcu Miłosierdzia (Pietà), obdarzonych nadzwyczajnymi zdolnościami głosowymi. I uznał, że podobna sytuacja każe pomyśleć o pokorze młodej Maryi, w której Bóg dokonał wielkich rzeczy. Bowiem „te pięć sierot jakby reprezentuje głos Maryi Dziewicy, zaś chór wyraża Kościół jako wspólnotę. Toteż Maryja i Kościół są zjednoczeni kantykiem chwały skierowanym do Świętego do Boga, który mocą swej miłości urzeczywistnia w historii swój plan sprawiedliwości. Na koniec chór udzielił głosu temu wysublimowanemu dziełu, jakim jest Ave verum Corpus Mozarta. W tym miejscu medytacja ustępuje miejsca kontemplacji, bo spojrzenie duszy pada na Najświętszy Sakrament, aby w nim rozpoznać Corpus Domini, to Ciało, które prawdziwie zostało złożone w ofierze na krzyżu i z którego wypłynęło źródło powszechnego zbawienia”. Papież przypomniał też, że Mozart skomponował ten motet niedługo przed śmiercią i być może dlatego jego muzyka staje się wprost modlitwą, oddaniem serca Bogu z głębokim poczuciem pokoju. $\mathrm{Z}$ tego względu ów koncert nie tylko zaspokoił smak estetyczny, ale także nakarmił ducha, którego udziela Bóg - źródło ludzkiego życia i pokoju.

Powyższe przemówienia mogą więc świadczyć o tym, że papież wykazywał się wielkim znawstwem, jeśli chodzi o twórczość wybitnych muzyków - kompozytorów i że - jak już była o tym mowa - potrafił odczytywać język muzyki, interpretować go, poddawać refleksji czy ukazywać słuchaczom głębię wykonanego dzieła muzycznego. Potwierdzeniem tego może być także papieski komentarz do trzech przepracowanych i wykonanych w czasie koncertu dzieł Liszta ${ }^{18}$. Papież powiedział wówczas, że „w tych trzech kompozycjach wyraziły się wszystkie możliwości muzyczne orkiestry, co pozwoliło słuchaczom usłyszeć z całą jasnością głosy specyficzne dla różnych sekcji, które tworzą zespół orkiestrowy: tj.: instrumenty smyczkowe, instrumenty dęte, drewniane (legni), instrumenty dęte blaszane (ottoni), perkusje; barwy głosów bardzo charakterystyczne i zróżnicowane między sobą. A mimo to nie dawało to wrażenia jakiejś masy dźwięków nie powiązanych ze sobą, a przeciwnie, wszystkie barwy orkiestrowe wyraziły jedyny sam w sobie plan muzyczny. To zaś dało odczuć słuchaczom piękno i radość słuchania, wzbudziło w sercach szeroką gamę odczuć: od radości i odświętności marszu do pogrążenia w zadumie - wskutek powracającej i przygniatającej melodii - jakie nasunęło wykonanie drugiego dzieła, aż do postawy modlitewnej, do której wezwało wstrząsające wykonanie Ave Maria".

18 Zob. Przemówienie po koncercie ofiarowanym przez prezydenta Republiki Węgier Pála Schmitta z okazji węgierskiej prezydencji w Radzie Unii Europejskiej oraz w 200. rocznicę urodzin Ferenca Liszta, Aula Pawła VI, 27.05.2011 (Festmarsch zur Goethejubiläumsfeier, Vallée d'Obermann i Ave Maria - Die Glocken von Rom). 


\subsection{Uniwersalny charakter muzyki i śpiewu}

Powszechnie uważa się, że muzyka i śpiew mają uniwersalny charakter. Nic więc dziwnego, że również Benedykt XVI często ten ich istotowy charakter podkreślał. Warto może prześledzić, w jakich okolicznościach i w jaki sposób to czynił. I tak przemawiając na spotkaniu z artystami w Kaplicy Sykstyńskiej powiedział, że w tym przepięknym otoczeniu fresków Michała Anioła Buonarottiego rozbrzmiewa często m.in. „powszechny język muzyki, dzięki geniuszowi wielkich muzyków, którzy oddali swą twórczość na służbę liturgii, pomagając duszy wznieść się ku Bogu"19.

Przemawiając po innym koncercie ${ }^{20}$ życzył słuchaczom, by harmonia śpiewu i muzyki, która nie zna barier społecznych i religijnych, stanowiła nieustanne zaproszenie dla wierzących i wszystkich ludzi dobrej woli do wspólnego poszukiwania uniwersalnego języka miłości, który sprawia, że ludzie stają się zdolni do budowania świata sprawiedliwości i solidarności, nadziei i pokoju.

Po koncercie wykonanym przez Kammerochester ${ }^{21}$ w Castel Gandolfo papież przemówił po niemiecku, ponieważ większość obecnych tam osób była niemieckiego pochodzenia. Na początku trochę żartobliwie zauważył, że po wydarzeniach związanych z budową wieży Babel języki wprowadzają podziały między ludźmi, że tworzą bariery. Natomiast słuchając muzyki, można poczuć, że pozostała jakaś jeszcze, niezburzona przez pychę budowniczych wieży, część świata, a jest nią właśnie muzyka. Jest ona tym szczególnym językiem, który mogą zrozumieć wszyscy, ponieważ wszystkich chwyta za serce. Daje to nie tylko gwarancję, że dobroć i piękno stworzenia Bożego nie uległy całkowitemu zniszczeniu, ale zarazem zapewnia, iż wszyscy zostaliśmy powołani, by pracować na rzecz dobra i piękna.

Wyraził też przekonanie, że wysłuchany koncert pozwolił przeżyć jedną godzinę jakby w raju, gdyż pozwolił zakosztować nieskażonego piękna i dobra stworzenia. Nie był jednak przy tym ani ucieczką od nędzy tego świata, ani też od codzienności, gdyż człowiek może przeciwstawiać się złu i ciemnościom tylko wtedy, gdy naprawdę uwierzy w dobro, a może uwierzyć w dobro tylko wówczas, gdy go doświadczy i przeżyje w sposób rzeczywisty. A ten koncert pozwolił właśnie dotknąć sercem dobra i piękna. Podkreślił wreszcie, że doświadczenie piękna muzyki stanowi także obietnicę, że przyszły świat jednak nadejdzie, że Bóg zwycięży, że

\footnotetext{
19 Przemówienie na spotkaniu z artystami, Kaplica Sykstyńska, 21.11.2009.

20 Przemówienie na zakończenie koncertu wykonanego ku czci Benedykta XVI przez orkiestrę Filharmonii z Monachium w Bawarii, Aula Pawła VI, 20.10.2005.

21 Przemówienie po koncercie ku czci papieża ofiarowanym przez Bayerisches Kammerorchester Bad Brücknau, Castel Gandolfo, 2.08.2009.
} 
piękno i dobro zwyciężą. Jest to oczywiście ogromną pociechą i pokrzepieniem duchowym w codziennej pracy, za które należy Bogu dziękować.

Doskonałą okazją, by ukazać uniwersalny charakter muzyki i śpiewu, okazał się zwłaszcza koncert wykonany przez Orkiestrę Filharmonii Chińskiej i chór Opery z Szanghaju ${ }^{22}$. Artyści chińscy - czyli przedstawiciele wielkiej tradycji kulturalnej i muzycznej Chin - wykonali bowiem w jego trakcie dzieła Mozarta z wielkim znawstwem, finezją i elegancją, dzieła, które niewątpliwie stanowią część najwspanialszego dziedzictwa artystycznego ludzkości. Chińscy muzycy dali tym samym świadectwo, że muzyka i w ogóle wielka sztuka mogą być uprzywilejowanymi nośnikami spotkania narodów i kultur, nośnikami wzajemnego poznania i szacunku pomiędzy różnymi ludami i kulturami. Papież wyraził przy tym życzenie, by bardziej doceniać tę powszechność języka sztuki, ponieważ chyba tylko ów język bywa środkiem porozumienia dostępnym dla wszystkich. Następnie z przyjemnością odnotował, że orkiestra i chór z Państwa Środka interesują się europejską muzyką religijną. Świadczy to bowiem o tym, że jest możliwe, by ludzie pochodzący z różnych światów kulturowych potrafili jednak kosztować i doceniać wzniosłe wyrazy ducha, powstałe w innej niż własna kulturze. Żywym tego świadectwem okazało się właśnie wykonane przez Chińczyków Requiem Mozarta. Muzyka interpretuje bowiem uczucia bliskie i zrozumiałe dla każdego człowieka, zwłaszcza uczucia religijne, które przekraczają wszelkie granice pojedynczej kultury. Papież nie omieszkał też wspomnieć, że swą myślą obejmuje cały naród chiński, przede wszystkim zaś wierzących w Chrystusa, których łączy szczególna więź duchowa z następcą św. Piotra. Zwrócił też uwagę - dając zapewne dużo do myślenia artystom niebędącym z pewnością chrześcijanami - że Requiem zrodziło się z tej wiary chrześcijańskiej, jako modlitwa wznoszona do Boga - sprawiedliwego i miłosiernego Sędziego - dotykająca wszystkich serc i udzielająca się jako wyraz humanizmu uniwersalnego.

Inną sprzyjającą okolicznością, znakomicie zresztą wykorzystaną przez papieża dla podkreślenia powszechnego czy uniwersalnego charakteru sztuki, był z kolei koncert West-Eastern Divan Orchestra ${ }^{23}$. Orkiestrę tę zorganizował Daniel Barenboim, którego rodzice przeżyli Shoah. A grają w niej nie tylko muzycy izraelscy, ale i palestyńscy, a nawet pochodzący z innych krajów arabskich; a więc osoby wyznające zarazem różne religie: hebrajską, muzułmańską i chrześcijańską. Idea takiej orkiestry zrodziła się u niego z przekonania, czy nawet bardziej z doświadczenia,

\footnotetext{
22 Przemówienie na zakończenie koncertu ofiarowanego i wykonanego przez Orkiestrę Filharmonii Chińskiej i przez Chór Opery Shanghai, Aula Pawła VI, 7.05.2008.

23 Przemówienie po koncercie ofiarowanym przez West-Eastern Divan Orkiestra, Castel Gandolfo, 11.07.2012.
} 
że muzyka łączy ludzi ponad wszelkimi podziałami. Aby to jak najlepiej zilustrować, papież posłużył się tzw. „rytem” strojenia instrumentów przed rozpoczęciem koncertu. W tym momencie audytorium słyszy jedynie kakofonię dźwięków wytwarzanych przez różne instrumenty, ale potem, w czasie koncertu właśnie z tych dźwięków powstaje sym-fonia, gdyż dopiero muzyka je harmonizuje. Nie dochodzi jednak do tego ani w sposób magiczny, ani też automatyczny, a jedynie dzięki cierpliwej, wytrwałej pracy dyrygenta i każdego z muzyków z osobna. Wymaga to oczywiście czasu i poświęcenia, wymaga wysiłku słuchania siebie nawzajem, także rezygnacji ze zbytniego wyróżniania się, a zamiast tego postawienia na pierwszym miejscu doskonałego efektu całego zespołu. Korzystając z tej analogii, papież wyraził pragnienie, by również w świecie realizowała się taka wielka symfonia pokoju wśród narodów.

W ramach tego właśnie koncertu została wykonana V i VI Symfonia Ludwiga van Beethovena, co okazało się zresztą bardzo wymowne. Bowiem te dwie niezwykle sławne symfonie wyrażają dwa aspekty ludzkiego życia, tj.: dramat i pokój, czyli z jednej strony walkę człowieka z przeciwnościami losu, z drugiej zaś zanurzenie w błogiej, pogodnej atmosferze czasu sielanki. Papież przypomniał przy tej okazji, że Beethoven pracował nad tymi dwiema symfoniami, a zwłaszcza nad ich ostatecznym ukształtowaniem i zakończeniem, niemal jednocześnie. Także jednocześnie zostały one po raz pierwszy wykonane podczas pamiętnego koncertu 22 grudnia 1808 roku w Wiedniu.

Wspominając o tym, papież chciał niejako przekazać światu swoiste orędzie: że mianowicie osiagnięcie pokoju wymaga zaangażowania, wyrzeczenia się przemocy i broni, wymaga przede wszystkim zaangażowania się poprzez osobiste i wspólnotowe nawrócenie, poprzez dialog, poszukiwanie możliwego porozumienia. Wyrażając uznanie dla profesjonalizmu muzyków oraz dla ich zaangażowania etycznego i duchowego, zapewnił o swej modlitwie oraz życzył, by poprzez uniwersalny język muzyki próbowali rozsiewać w świecie nadzieję.

Benedykt zwrócił uwagę na uniwersalny charakter języka muzycznego w innym jeszcze przemówieniu. Po koncercie, który był podarunkiem dla niego z okazji 80 . urodzin ${ }^{24}$ powiedział, że mowa muzyki jest uniwersalna, co można dostrzec, obserwując ludzi pochodzących z zupełnie różnych kultur i wyznających różne religie, którzy mimo to pozwalają, aby ta szczególna mowa ich ujęła i do pewnego stopnia poprowadziła, a nawet uczyniła jej interpretatorami. Ta uniwersalność muzyki staje się dzisiaj jeszcze bardziej oczywista dzięki elektronicznym i digitalnym możliwościom komunikowania się. Niezliczona liczba ludzi w różnych krajach może

\footnotetext{
24 Przemówienie po koncercie Orkiestry Symfonicznej Radia i Telewizji w Stuttgarcie ku czci papieża z okazji jego 80. urodzin, Aula Pawła VI, 16.04.2007.
} 
bowiem teraz w miejscach swego zamieszkania uczestniczyć w wykonaniach muzycznych, a nawet odtwarzać je w dowolnym czasie. Papież wyraził też przekonanie, że muzyka, jaką wykonano podczas tego koncertu, tj. utwory wielkiego Mozarta, Gabrielego czy Dvoraka, przemawiają takim właśnie powszechnym językiem piękna, zdolnym łączyć ze sobą ludzi dobrej woli na całej ziemi, kierując zarazem ich wzrok ku Wysokościom i otwierając na Dobro i Piękno absolutne, mające swe ostateczne źródło w Bogu. Dlatego życzył zebranym, by wielkość i piękno muzyki mogły nieustannie i wciąż na nowo inspirować do budowania świata miłości, solidarności i pokoju. Na koniec wezwał wszystkich wykonawców i słuchaczy, by uciekali się do nieustannej opieki Bożej miłości, który wciąż pragnie zapalać w sercach płomień dobra i ożywiać go swą łaską.

W czasie koncertu, który został ofiarowany Benedyktowi przez organizację ENI z okazji zakończenia prac restauracyjnych przy bazylice watykańskiej, wykonano trzy dzieła muzyczne ${ }^{25}$ : symfonię Haydna, Fantasia Corale Beethovena oraz utwór Arvo Pärta, Cecilia, vergine romana, ożywiając niejako te nieśmiertelne dzieła. Benedykt w sposób bardzo wysublimowany przeanalizował potem te dzieła. Powiedział, że opery Haydna i Beethovena pozwoliły wybrzmieć całemu bogactwu i mocy muzyki symfonicznej okresu klasycznego i romantycznego, gdzie geniusz ludzki współzawodniczy w kreatywności z naturą, dając życie harmoniom różnym i różnorodnym, gdzie także ludzki głos uczestniczy w tym języku, który jest jakby odbiciem wielkiej symfonii kosmicznej. Wyjaśnił, że taka forma bywa charakterystyczna przede wszystkim dla okresu romantycznego i późnoromantycznego, ale równocześnie poza ten okres wykracza, przedstawiając uniwersalny wymiar sztuki, uniwersalny sposób pojmowania człowieka i jego miejsca w świecie. Natomiast Pärt chciał - w jego przekonaniu - przy pomocy orkiestry symfonicznej i chóru dać głos innej rzeczywistości, która nie należy do świata naturalnego; oddał bowiem głos świadectwu wiary w Chrystusa, które wyraża się w jednym słowie - martirium, a które uosabia się w św. Cecylii, męczennicy i patronce muzyki i śpiewu kościelnego. Zauważył następnie, że połączenie tekstu o męczeństwie św. Cecylii z operami Haydna i Beethovena zestawia go z nimi w pewnym pobudzającym do myślenia kontekście, zaś znamienny styl, który interpretuje tekst męczeństwa świętej w kluczu muzycznym, przedstawia miejsce i zadanie wiary we wszechświecie. Pośród sił witalnych natury, które otaczają człowieka, a także są i w nim samym, wiara jest bowiem siłą inną niż siły naturalne, jest siłą, która odpowiada na słowo głębokie, co wyszło z ciszy, jak powiedziałby św. Ignacy Antiocheński. Podkreślił mocno, że słowo wiary potrzebuje wielkiej ciszy wewnętrznej, aby słuchać i być

\footnotetext{
25 Por. Przemówienie po koncercie na zakończenie prac restauracyjnych przy bazylice watykańskiej ofiarowanym przez organizację ENI, Aula Pawła VI, 1.10.2010.
} 
posłusznym Słowu, które jest ponad tym, co widzialne i dotykalne. Że głos ten przemawia również poprzez zjawiska natury, ponieważ jest mocą; że Słowo powołało do istnienia świat i nim zarządza. Żeby jednak usłyszeć ten głos, potrzeba serca pokornego i posłusznego. Wiara podąża więc za tym głębokim głosem tam, gdzie sama sztuka nie może już dotrzeć; idzie za nią drogą świadectwa, drogą ofiary z samego siebie przez miłość, jak to uczyniła Cecylia. A zatem najpiękniejszym dziełem sztuki, arcydziełem bytu ludzkiego jest każdy akt autentycznej miłości, poczynając od najmniejszego męczeństwa w życiu codziennym, aż po heroiczne poświęcenie. Bo tutaj samo życie czyni siebie śpiewem, jest antycypacją symfonii, jaką będą śpiewać święci w niebie.

\subsection{Egzystencjalny wymiar języka muzyki i śpiewu}

Papież emeryt w przemówieniu dziękującym za nadanie mu tytułu doktora honoris causa, wskazał na trzy źródła, z których rodzi się muzyka: doświadczenie miłości, doświadczenie smutku pochodzącego z dotknięcia śmiercią, bólem i otchłaniami istnienia oraz spotkanie z tym, co Boże ${ }^{26}$. W tym miejscu chcę omówić te wypowiedzi, w których ukazał on egzystencjalne zmagania się kompozytora z bolesną rzeczywistością życia. Należy bowiem przyznać, że niemal w każdym przemówieniu papież wskazywał również na egzystencjalny wymiar języka wykonanego dzieła. Niemniej jednak w dwóch przemówieniach uczynił to w sposób niezwykle wyrazisty, zwłaszcza po wykonaniu głównego dzieła liederystyki Schubertiańskiej: Die Winterreise (Podróż zimowa) ${ }^{27}$. Aż 24 pieśni (Lieder) Schuberta skomponowane do liryki Wilhelma Müllera wyrażają napiętą atmosferę smutnej samotności, jakiej doświadczała jego dusza, wyczerpana długą chorobą i niemałymi rozczarowaniami uczuciowymi i zawodowymi. Jego dzieło jest więc całkowicie wewnętrzną podróżą, którą słynny kompozytor austriacki opisał w 1827 roku, tj. rok przed przedwczesną śmiercią, jaka go spotkała w wieku 31 lat.

Kiedy Schubert włączył tekst poetycki do swojego dźwiękowego wszechświata, zinterpretował go przez splot melodyczny, który przenika pewną słodyczą duszę słuchacza, wprowadzając go zarazem w doświadczenie przepełnione tęsknotą i żalem. W ten sposób kompozytor językiem muzyki przypomina prawdy serca, które wyrastają ponad wszelkie rozumowania. I w wyobraźni rodzi się tym samym fresk, który przemawia na przemian zwykłą codziennością, nostalgią, introspekcją, przyszłością. To wszystko rozkwita podczas wybrzmiewającej muzyki. Pojawia się śnieg, krajobraz, przedmioty, osoby, wydarzenia; wszystko to płynnie pogrąża

26 Por. R. Tyrała, Benedykt XVI doktorem „honoris causa”..., dz. cyt., s. 25-26.

27 Zob. Przemówienie po koncercie wykonanym ku czci papieża, Castel Gandolfo, 24.08.2008. 
się w pełnych tęsknoty wspomnieniach. Oryginalnością tego wykonania - jak zauważył papież - było to, że zastąpiono ludzki głos grą na wiolonczeli. Co prawda nie słychać było słów poezji, ale zawarte w niej uczucia wyrażał niemal ludzki "głos" tego instrumentu.

Benedykt XVI przypomniał również, że Schubert, prezentując przyjaciołom Podróż zimową, miał powiedzieć: „zaśpiewam cykl pieśni (Lieder), które mnie tak poruszyły, jak nigdy wcześniej się to nie wydarzyło. Podobają mi się najbardziej ze wszystkich i wam się spodobają”. I przyznał, że po wysłuchaniu tych pieśni i pamiętając o nadziei płynącej z wiary katolickiej, można by się zgodzić ze słowami kompozytora. Bowiem młody Schubert, spontaniczny i kipiący życiem, rzeczywiście potrafił przekazać to, co przeżywał i czego doświadczał. Dlatego ten słynny geniusz muzyczny zasłużył sobie na szczególne uznanie, jakim jest powszechnie obdarzany i jakiego czci cywilizacja europejska, a nawet wielka kultura oraz duchowość chrześcijańska. Pozostawiając po sobie ponad 600 pieśni, zasłużył na miano „księcia pieśni” (Lieder) i jak mówi epitafium, „kazał śpiewać poezji i przemawiać muzyce".

Inną okazją do podkreślenia, że język muzyki może przekazywać ważne treści egzystencjalne, było wykonanie Mszy Requiem Giuseppe Verdiego ${ }^{28}$, skomponowanej w 1873 roku z okazji śmierci Alessandro Manzoniego, którego kompozytor podziwiał i nieomal czcił. Powstałe ze znajomości z pisarzem i niedające się inaczej opisać uczucia, Verdi wyraził, komponując tę właśnie Mszę, czyli Requiem. W zamyśle kompozytora miało to być dzieło zarazem kulminacyjne i finalne w jego twórczości muzycznej. Ale nie stało się ono jedynie homagium dla wielkiego pisarza, lecz okazało się również odpowiedzią na artystyczną, wewnętrzną i duchową potrzebę, zestawienia Manzoniego z naturą ludzką i chrześcijańską, którą kompozytor tak bardzo podziwiał.

Przy tej okazji papież przypomniał, że Verdi spędził życie na badaniu serca człowieka, a w swych dziełach wydobywał na światło dzienne dramaty ludzkiego życia i przy pomocy muzyki przedstawiał historie różnych osobowości. Jego teatr jest zapełniony ludźmi nieszczęśliwymi, prześladowanymi, będącymi ofiarami zła. $\mathrm{Na}$ wielu stronach Messa da Requiem wybrzmiewa tragiczna wizja losów ludzkich. Autor dotyka takich sytuacji, jak nieunikniona śmierć oraz fundamentalna kwestia świata transcendentnego. Nie posługując się elementami sceny, ale przy pomocy samych słów liturgii katolickiej i przy pomocy muzyki, przedstawia całą gamę przeżyć, jakie towarzyszą człowiekowi pod koniec życia: tj. udrękę w konfrontacji ze swą własną kruchą naturą, odczucie buntu przed śmiercią czy przerażenie

\footnotetext{
28 Zob. Przemówienie po koncercie ku czci papieża ofiarowanym przez maestro Enocha zu Guttenberga, Aula Pawła VI, 16.10.2010.
} 
u progu wieczności. Muzyka Verdiego zaprasza do refleksji nad sprawami ostatecznymi i nad stanem ducha ludzkiego, przedstawianych przez kompozytora przy pomocy kontrastów form, tonacji, kolorytów, w których przeplatają się momenty dramatyczne z momentami naznaczonymi nadzieją.

Jednak Verdi - jak podkreślił papież - nie zatrzymuje się na poziomie samego opisu ludzkich przeżyć w obliczu śmierci, lecz równocześnie prowadzi do Boga. W swym słynnym liście do wydawcy Ricordiego określił samego siebie jako trochę ateistę. Napisał tę Mszę jako wielki apel do odwiecznego Ojca, skierowany doń w chwili, gdy próbował pokonać krzyk desperacji wobec śmierci, aby odnaleźć oddech życia, które przemienia się w cichą, milczącą i pełną zgryzoty modlitwę: Libera me, Domine. Requiem Verdiego zaczyna się w frazą w a-moll, która zdaje się schodzić niemal ku ciszy - kilka taktów wiolonczel, pianissimo, con sordino [z tłumikami] - a kończy się stonowanym wezwaniem do Pana Libera me. Ta muzyczna katedra objawia się jako opis duchowego dramatu człowieka w obecności Boga Wszechmogącego, człowieka, który nie może uchylić się od odwiecznego pytania o własne istnienie.

Po napisaniu Messa da Requiem - kontynuował papież - Verdi przeżywał rodzaj drugiego „sezonu kompozytorskiego”, który zamknął się muzyką religijną: Pezzi sacri. Jest ona znakiem jego niepokoju duchowego, znakiem, że gorące pragnienie Boga jest wpisane w serce każdego bytu ludzkiego i dlatego ludzka nadzieja spoczywa w Panu. Autor wyraził to słowami: „Qui Mariam absolvisti, et latronem exaudisti, mihi quoque spem dedisti” (Ty, który Marii [Magdalenie] przebaczyłeś i wysłuchałeś dobrego łotra, także mnie dałeś nadzieję)”. W ten sposób Verdi stworzył wielki fresk muzyczny - mówił papież - który w słuchaczach odnawia pewność słów św. Augustyna: „Niespokojne jest serce człowieka, dopóki nie spocznie w Panu”. Możliwość wysłuchania tego koncertu budzi więc wdzięczność wobec Boga i wykonawców za to, że dane było zakosztować prawdziwego piękna, zdolnego do podniesienia na duchu.

Owe niezwykłe zdolności wczuwania się Verdiego w egzystencjalne problemy człowieka dały Benedyktowi XVI okazję do własnej wypowiedzi po ostatnim koncercie za jego pontyfikatu ${ }^{29}$, podczas którego wykonano symfonię pt. La forza del destino dla uczczenia dwusetnej rocznicy urodzin kompozytora. W swym przemówieniu papież ponownie podkreślił, że w jego dziełach uderza zawsze to, iż potrafił uchwycić sytuacje, a przede wszystkim stany ducha ludzkiego, o których opowiadał muzycznie w sposób tak bezpośredni, zwięzły i istotny, jak to rzadko

29 Zob. Przemówienie po koncercie ofiarowanym przez ambasadę Włoch przy Stolicy Świętej ku czci papieża i prezydenta Republiki Włoskiej Giorgia Napolitana z okazji 84. rocznicy traktatów laterańskich, Aula Pawła VI, 4.02.2013. 
zdarza się w panoramie muzycznej. Zawsze chodziło o przeznaczenie tragiczne. I od takiego przeznaczenia nie odstają bohaterowie dzieła La forza del destino. Jest to widoczne już od pierwszych taktów. Jednak zajmując się kwestią przeznaczenia, Verdi znalazł się w bezpośredniej konfrontacji z rzeczywistością religijną, w konfrontacji z zagadnieniem Boga, wiary i Kościoła. Na tym tle - jak zauważył Benedykt XVI - wyłonił się obraz duszy muzyka, jego niepokój, poszukiwania religijne. W La forza del destino wbudowana została jedna z najsłynniejszych arii pt. La Vergine degli angeli, która jest zarazem smutną modlitwą. Jednak obok niej znajdują się tam jeszcze dwie historie nawrócenia i zbliżenia się do Boga. Mianowicie historia Eleonory, która dramatycznie rozpoznaje swoje winy i decyduje się wycofać do życia pustelniczego oraz historia don Alvaro, który zmaga się pomiędzy życiem w świecie a życiem w samotności z Bogiem. Aby lepiej ukazać tę dramaturgię, papież zwrócił uwagę na to, że w dwóch wersjach tej samej opery, tj. z 1862 roku dla Petersburga i tej z 1869 roku dla La Scala w Mediolanie, dał inne zakończenia. W pierwszej wersji don Alvaro kończy swe życie samobójstwem, odrzucając habit zakonny i wzywając siły piekielne. W drugiej natomiast przyjmuje słowa brata gwardiana, by zaufał miłosierdziu Bożemu i opera kończy się słowami: salita a Dio - tj. wstąpieniem do Boga. Jak widać, w tej operze Verdi nakreślił dramat ludzkiej egzystencji, naznaczony tragicznym losem człowieka, a także nostalgią za Bogiem, Jego miłosierdziem i miłością, które dają światło, nadają sens i nadzieję także wówczas, gdy jesteśmy pogrążeni w życiowych ciemnościach. Wiara daje tę perspektywę, która nie jest iluzoryczna, lecz rzeczywista, zgodnie z tym, o czym zapewnia św. Paweł, że żadne moce ani okoliczności życiowe nie zdołają odłączyć człowieka wierzącego od Chrystusa (Rz 8, 38-39). Jest to moc chrześcijanina, która wyrasta ze śmierci i zmartwychwstania Pana, z najwyższego aktu Boga, który wszedł w historię człowieka, i to nie tylko przez słowo, ale także przez wcielenie.

W czasie tego ostatniego koncertu ofiarowanego Benedyktowi XVI wykonano również III Symfonię Beethovena, początkowo zadedykowaną Napoleonowi, ale po ogłoszeniu się przez tego ostatniego imperatorem, kompozytor zmienił tytuł: skomponowana dla upamiętnienia wielkiego człowieka. W tym dziele Beethoven wyraża w formie muzycznej ideał bohatera wolności i równości, który stoi przed zasadniczym wyborem: rezygnacji lub walki, śmierci lub życia, poddania się lub zwycięstwa. Kompozytor opisuje te stany ducha przy pomocy całego bogactwa kolorystycznego i tematycznego aż do owego czasu nieznanego. Szczególne wrażenie na papieżu zrobiła słynna Marcia funebre - marsz pogrzebowy, który jest smutną medytacją o śmierci. Rozpoczyna się ona pierwszą sekcją tonów dramatycznych i wyrażających strapienie, ale w części centralnej pojawia się epizod radosny, pogodny, zaintonowany przez obój, a potem następuje podwójna fuga i dźwięki trąby. Myśl o śmierci zaprasza do refleksji nad tym, co jest ponad nami, tj. nad 
nieskończonością. W tamtych latach - jak przypomniał papież - Beethoven w testamencie heiligenstadzkim z października 1802 roku napisał: „Boże, Ty z wysoka patrzysz na moje wnętrze, znasz je i wiesz, że jest napełnione miłością do ludzi i pragnieniem czynienia dobra”. Poszukiwanie sensu, który mógłby nas otworzyć na nadzieję solidną i na pewną przyszłość, jest częścią pielgrzymowania ludzkości.

\subsection{Humanizujący charakter muzyki i śpiewu}

Muzykolodzy wskazują, że z dorobku naukowego Josepha Ratzingera wynika, iż muzyka przedstawia „bezcenną pomoc w rozwoju własnego człowieczeństwa prowadzącego go do Stwórcy" ${ }^{30}$. Nie inaczej jest w jego wypowiedziach papieskich. O tym humanizującym charakterze muzyki i śpiewu mówił papież w wielu swych przemówieniach. Jednym z nich było przemówienie po koncercie kwartetu z Berlina ${ }^{31}$. Papież podkreślił wtedy, że wspólny śpiew domaga się od pojedynczego śpiewaka zaangażowania wszystkich zdolności technicznych i muzykalnych w wykonanie przynależnej mu części utworu, a jednocześnie uważnego wsłuchiwania się w śpiew innych. Tylko wówczas, gdy wszyscy będą to potrafili, tzn. jeśli nikt nie będzie stawiał siebie w centrum uwagi, ale w duchu służby włączy się w pracę zespołu, czy też odda się do dyspozycji jako swoiste „narzędzie” realizujące myśl kompozytora, tak aby mogła ona odpowiednio wybrzmieć i tym samym dotrzeć do serc słuchaczy; tylko wtedy interpretacja utworu muzycznego może być prawdziwie wielka. I podkreślił, że taką właśnie wielką interpretację zaprezentował kwartet o międzynarodowej sławie, który wykazał się perfekcyjną umiejętnością wspólnego śpiewu, wielkim bogactwem wyrazu w delikatnych odcieniach barwy głosu i wspaniałą harmonijnością całego zespołu. Benedykt XVI zasugerował jednocześnie, że podobne współdziałanie może być wzorem dla członków społeczności Kościoła, którzy także powinni starać się być „narzędziami” - w przekazywaniu myśli wielkiego „Kompozytora”, bo Jego dziełem jest harmonia wszechświata.

Dalej podkreślił, że usłyszane kompozycje zachęciły słuchaczy, aby zaczęli medytować nad złożonością życia, a nawet małych codziennych spraw. Każdego dnia splatają się bowiem nasze radości i cierpienia, nasze nadzieje i rozczarowania, nasze oczekiwania i zaskoczenia, które nieustannie na siebie się nakładają i wzbudzają we wnętrzu człowieka fundamentalne pytania: Skąd, dokąd i ku czemu idziemy? - Pytania o prawdziwy sens ludzkiej egzystencji. Muzyka ma to do siebie, że wyraża te wszystkie przeżycia duchowe i oferuje możliwości przejrzenia się - jakby

\footnotetext{
30 Por. R. Tyrała, Benedykt XVI doktorem „honoris causa”..., dz. cyt., s. 24.

31 Zob. Przemówienie po koncercie ku czci papieża ofiarowanym przez prezydenta Republiki Federalnej Niemiec, 18.11.2006.
} 
w lustrze - tak w ciągu wydarzeń osobistych, jak i w historii powszechnej. Ale oferuje jeszcze coś więcej: mianowicie poprzez swoje dźwięki przenosi słuchaczy w inny świat i harmonizuje ich wnętrza. W tych chwilach spokoju, jakie ofiaruje, słuchacze są w stanie przyjrzeć się, jakby z wysokiego pułapu, tajemniczej rzeczywistości, którą chcieliby odczytać i w świetle wiary lepiej zrozumieć.

Faktycznie, historia świata może się nam jawić jako wspaniała symfonia, którą skomponował Bóg i której wykonaniem, jako mądry Mistrz sam dyryguje - stwierdził Benedykt XVI. Jeśliby nawet jakaś partytura wydawała się ludziom skomplikowana i trudna, to jednak On zna ją od pierwszej do ostatniej nuty. Człowiek nie powinien więc brać do ręki batuty dyrygenta, a tym bardziej zmieniać melodii według własnego upodobania. Do każdego należy natomiast to, by na swym miejscu i przy swoich zdolnościach współpracował z wielkim Mistrzem w wykonywaniu tego wspaniałego arcydzieła. I być może dopiero w trakcie jego wykonywania będzie mu dane lepiej zrozumieć wspaniały plan Boskiej partytury.

W ten sposób - wedle papieża - muzyka doprowadza do modlitwy; zaprasza, by wznieść swą myśl ku Bogu, by w Nim odnaleźć podstawy nadziei i podtrzymanie na duchu w trudnościach życiowych. Wierni Jego przykazaniom i szanujący Jego zbawczy plan mogą razem budować taki świat, w którym będzie rozbrzmiewała melodia miłości. Co więcej, to sam Duch Święty może sprawić, że wierzący staną się niejako „narzędziami” - czyli dobrze zharmonizowanymi i odpowiedzialnymi współpracownikami cudownego wykonania, w którym wyraża się poprzez wieki plan powszechnego zbawienia.

\subsection{Edukacujna rola śpiewu}

Z kolei edukacyjną rolę śpiewu omówił papież w przemówieniu do chórów góralskich ${ }^{32}$. Podkreślił, że wychowanie do śpiewu, czy nawet więcej, do śpiewania w chórze, nie jest tylko ćwiczeniem słuchu oraz siły i piękna głosu, lecz jest równocześnie kształceniem „słuchu” duchowego, czyli „słuchu” serca, tj. ćwiczeniem i wychowaniem do życia w pokoju. Bowiem śpiewanie zespołowe, chóralne, a nawet we wspólnocie wielu chórów, wymaga szczególnej czujności, wymaga zwracania uwagi na innych, na kompozytora, dyrygenta, czy wreszcie na całość, którą zwykło się nazywać muzyką i kulturą. W ten sposób śpiewanie w chórze oznacza też, że wychowujemy siebie i innych do życia wspólnotowego, że wychowujemy się do pokoju, że możemy podążać razem naprzód. Stąd papież wyraził pragnienie, by ta piękna muzyka angażowała również do życia w pokoju z innymi ludźmi.

\footnotetext{
32 Zob. Przemówienie po koncercie chórów góralskich ofiarowanym przez diecezję Belluno-Feltre, Lorenzago di Cadore, 20.07.2007.
} 
O wychowawczej roli muzyki powiedział Benedykt XVI parę słów przy innej jeszcze okazji, mianowicie po koncercie ofiarowanym mu przez prezydenta Republiki Włoskiej - Giorgia Napolitana na 3. rocznicę pontyfikatu ${ }^{33}$. Podkreślił wtedy, że muzyka, podobnie jak cała sztuka, wychowuje, zwłaszcza ludzi młodych, do tego, by znajdywali upodobanie w autentycznym pięknie, ukierunkowuje ich także ku budowaniu społeczeństwa opartego na ideałach duchowych. Dlatego Włochy, dzięki swej niezliczonej liczbie dzieł materialnej i duchowej sztuki, okazują się uniwersalnym heroldem wszystkich wartości w sztuce zawartych. Zwłaszcza świąteczny charakter śpiewu i muzyki wydaje się być nieustannym zaproszeniem skierowanym do ludzi wierzących oraz do ludzi dobrej woli, by angażowali się w przygotowywanie przyszłości bogatej w nadzieję.

\section{Teologalny charakter muzyki i śpiewu}

\subsection{Chrześcijańskie korzenie}

Niezaprzeczalną jest rzeczą, że wielkie opowiadania biblijne, tematy, obrazy, przypowieści zainspirowały niezliczoną liczbę artystów do tworzenia arcydzieł, a zarazem przemawiały do serca każdego pokolenia wierzących poprzez te dzieła, w tym również dzieła muzyczne ${ }^{34}$. Papież analizując psalmy ${ }^{35}$, wykazywał, że stamtąd wywodzi się chrześcijański śpiew i towarzysząca mu muzyka jako modlitwa, w czasie której człowiek prowadzi dialog z Bogiem, przedstawia Mu swe życie, ze wszystkimi jego jasnymi i ciemnymi stronami i przemienia je tak, że staje się drogą do Niego.

Wiele świadectw starożytności chrześcijańskiej poświadcza stosowanie języka muzyki i śpiewu w życiu religijnym. Na Zachodzie ważną postacią pod tym względem był św. Ambroży, utalentowany autor wielu hymnów, ale też uzdolniony pod względem muzycznym. Na Wschodzie szczególnym przykładem jest Roman Pieśniarz, który żył na przełomie V/VI wieku w Syrii i Konstantynopolu i na którego zwrócił uwagę papież w swej środowej katechezie ${ }^{36}$. Ten wielki teolog, poeta i kompozytor przypomina cały skarbiec kultury chrześcijańskiej, zrodzonej z wiary w sercu, które spotkało się z Chrystusem, Synem Bożym. „To właśnie z tego

\footnotetext{
33 Zob. Przemówienie po koncercie ofiarowanym przez prezydenta Republiki Włoskiej Giorgia Napolitana ku czci papieża z okazji 3. rocznicy jego pontyfikatu, 24.04.2008.

34 Zob. Przemówienie na spotkaniu z artystami, Kaplica Sykstyńska, 21.11.2009.

35 Por. T. Samulnik, Biblijne i systematyczne źródta teologii muzyki Josepha Ratzingeral Benedykta XVI, „Pro Musica Sacra” 16 (2018), s. 131-133.

36 Zob. Katecheza w czasie audiencji generalnej, Roman Pieśniarz, Aula Pawła VI, 21.05.2008.
} 
spotkania ludzkiego serca z Prawdą, która jest Miłością, zrodziła się wielka kultura chrześcijańska”. A jeśli wiara pozostaje żywa, wówczas to dziedzictwo kultury nie zamiera, lecz trwa i się rozwija. Tak jak obrazy czy katedry powstałe w minionych wiekach nie są jedynie pomnikami przeszłości, ale domami modlitwy i życia, gdzie ludzie wierzący czują się "w domu», gdzie spotykają Boga i spotykają się we wspólnocie, tak samo wielka muzyka - gregoriańska czy Mozarta - nie jest sprawą przeszłości, lecz żyje żywotnością liturgii i ludzi wierzących. Jeśli wiara jest żywa, to i dziś znajdą się ludzie, którzy odpowiedzą na imperatyw powtarzający się w Psalmach: „Śpiewajcie Panu pieśń nową”.

W średniowieczu walnie przyczynili się do ukształtowania kultury europejskiej benedyktyni i cystersi. Ich głównym celem nie było tworzenie nowej kultury jako takiej, ale poszukiwanie Boga - querere Deum ${ }^{37}$. Słowo Boże, zwłaszcza w księdze Psalmów, podsuwało im słowa, którymi mogli się do Niego zwracać w modlitwie i śpiewać z użyciem instrumentów muzycznych. W ten sposób z Psalmów uczyli się, że aby modlić się słowem Bożym, nie wystarczy wymawianie słów, ale konieczna jest muzyka. Benedykt XVI wykazuje, że wielka muzyka zachodnia zrodziła się z głębokiej potrzeby człowieka rozmawiania z Bogiem i wielbienia Go słowami danymi przez Niego. Nie była to twórczość indywidualna, której celem byłoby manifestowanie swego ,ja” i zbudowanie sobie pomnika. „Było to ważne rozpoznawanie «uszami serca» podstawowych praw muzycznej harmonii stworzenia, zasadniczych form muzyki, jaką Stworzyciel napełnił świat i człowieka, i było poszukiwanie muzyki, która będąc godna Boga, jest zarazem naprawdę godna człowieka i we wzniosły sposób tę godność głosi”.

Po koncercie ${ }^{38}$, który miał bogaty repertuar utworów: od Palestrina aż do Richarda Wagnera, od Wolfganga Amadeusa Mozarta aż do Giuseppe Verdiego i Hansa Pfitznera, papież zauważył, że artyści pozwolili zasmakować choć małej części ogromnego obszaru twórczości muzycznej, która ostatecznie inspirowała się zawsze i żywiła korzeniami chrześcijańskiej Europy. Co prawda Wagner, Pfitzner i Verdi odsłaniają zupełnie nowe obszary doświadczania rzeczywistości, zawsze jednak możemy u nich odnaleźć obecność owego wspólnego fundamentu ducha europejskiego, który został ukształtowany przez chrześcijaństwo. Podkreślił, że także podczas tego koncertu słuchacze mogli doświadczyć, jak muzyka tak wysokiego poziomu oczyszcza i podnosi, a ostatecznie pozwala odczuwać wielkość i piękno Boga. Dziękując wykonawcom i wszystkim, którzy przyczynili się

37 Zob. Przemówienie do przedstawicieli świata kultury, Paryż, Collegium Bernardinum, 12.09.2008.

38 Przemówienie na zakończenie koncertu wykonanego ku czci Benedykta XVI przez orkiestrę Filharmonii z Monachium w Bawarii, Aula Pawła VI, 20.10.2005. 
do realizacji tego koncertu, Benedykt XVI dziękował również za to, że pomogli wznieść ducha ku Bogu.

Po koncercie wykonanym z okazji tysiąclecia archidiecezji Bamberg ${ }^{39}$ papież powiedział, że przytrafiło mu się właśnie coś, co mogło przytrafić się także innym słuchaczom: mianowicie, cudowne dźwięki symfonii pozwoliły mu zapomnieć o codzienności i przeniosły go w świat muzyki, która dla Beethovena oznaczała „objawienie wyższego - niż jakakolwiek wiedza czy filozofia - stopnia”. Przyznał, że muzyka potrafi wynosić ponad siebie samą, aż do Stwórcy wszelkiej harmonii, wzbudzając w ludziach szczególny oddźwięk, który stanowi jakby współbrzmienie piękna i prawdy Boga - tj. tej rzeczywistości, której żadna ludzka mądrość ani żadna filozofia nie są w stanie lepiej wyrazić. Zapewne coś podobnego miał na myśli Schubert, kiedy o menuecie Mozarta powiedział: „Wydaje się, że uczestniczą w nim aniołowie ze swym śpiewem”. I tego samego doświadczył papież podczas wykonywanego koncertu, dzięki szerokiej gamie barw głosów oraz dzięki odznaczającej się wielką siłą ekspresji interpretacji dwóch usłyszanych arcydzieł muzyki (Beethovena i Schuberta). Podobnie po koncercie z okazji 110. rocznicy urodzin Pawła $\mathrm{VI}^{40}$ Benedykt zauważył, że wykonawcy pięknych fragmentów dzieł Vivaldiego, Bacha i Mozarta umocnili ducha słuchaczy i dzięki głębokim emocjom pomogli im uchwycić w języku muzycznym wewnętrzną harmonię Bożego piękna.

Po koncercie wykonanym przez orkiestrę symfoniczną i chór symfoniczny im. Giuseppe Verdiego z Mediolanu ${ }^{41}$ papież stwierdził, że z pewnością wszyscy odczuli radość z wysłuchania porywających dzieł kompozytorów Luciana Beria, Johannesa Brahmsa i Ludwiga van Beethovena. Przypomniał zarazem, iż muzyka Brahmsa ubogaciła niegdyś religijną ufność dzieła Canto del destino Hölderlina. I uznał, że ów fakt może zachęcać do rozważenia wartości duchowej sztuki muzycznej, powołanej w sposób szczególny do wlewania nadziei w duszę człowieka, tak często naznaczoną cierpieniem i bardzo poranioną życiem ziemskim. Faktycznie bowiem istnieje tajemnicze i głębokie pokrewieństwo pomiędzy muzyką a nadzieją, pomiędzy śpiewem a życiem wiecznym. Nie bez powodu tradycja chrześcijańska przedstawia szczęśliwe duchy w niebie jako chóry śpiewaków porwanych majestatem Boga i przeżywających ekstazę w obliczu Bożego piękna.

\footnotetext{
39 Zob. Przemówienie po koncercie z okazji obchodów tysiąclecia archidiecezji Bamberg, Castel Gandolfo, 4.09.2007.

40 Przemówienie po koncercie z okazji 110. rocznicy urodzin papieża Pawła VI, Castel Gandolfo, 26.09.2007.

41 Zob. Przemówienie po koncercie ofiarowanym przez prezydenta Republiki Włoskiej Giorgia Napolitana ku czci papieża z okazji 3. rocznicy jego pontyfikatu, 24.04.2008.
} 
Nikt jednak - jak przestrzegał papież - nie powinien sądzić, że autentyczna sztuka i modlitwa mogą wyobcowywać człowieka z codzienności, bo jest nawet przeciwnie, do niej go odsyłają, „nawadniając” niejako aktywność człowieka i przyczyniając się do tego, że ziarna dobra kiełkują, aby wydać owoce dobra i pokoju. Młode pokolenia mogą więc czerpać z dziedzictwa artystycznego, znajdując w nim wciąż nowe inspiracje dla budowania świata bardziej sprawiedliwego i solidarnego i doceniając równocześnie tę wielką rolę, jaką liczne dzieła kultury światowej spełniają w służbie człowiekowi.

Podobnie wypowiedział się także $\mathrm{e}^{22}$ po koncercie, podczas którego orkiestra Wiener Philharmoniker wykonała po mistrzowsku VI Symfonię Antona Brucknera, tj. utwór przesycony duchem religijnym i głębokim mistycyzmem, toteż dzięki temu ta cudowna muzyka mogła dotrzeć do serc słuchaczy i dotknąć wszystkich stron ludzkiej wrażliwości. W ten sposób papież podkreślił, że dzięki pięknu skomponowanego utworu, a także dzięki muzycznemu talentowi wykonawców, myśl słuchaczy mogła przenieść się ze sfery ludzkiej w sferę Boską.

\subsection{Chrześcijański charakter europejskiej kultury muzycznej}

W obecnych czasach, czasach ateizacji, sekularyzacji, odrzucania chrześcijaństwa i relatywizowania wszelkich wartości, kolejni papieże, jak też biskupi i katolicy świeccy starają się mocno podkreślać chrześcijański charakter kultury europejskiej. A znakomitą częścią tej kultury jest przecież kultura muzyczna. Dlatego Benedykt XVI bardzo często uwypuklał ten jej charakter w różnych przemówieniach. W tym miejscu chciałbym przytoczyć dwa tego rodzaju przemówienia. Pierwsze wygłosił papież po pięknym koncercie orkiestry bawarskiej, która pozwoliła słuchaczom zanurzyć się w muzyce dwóch arcydzieł Antona Brucknera Te Deum i IX Symfonii. Na wstępie przypomniał ${ }^{43}$ ważne szczegóły z życia kompozytora. Otóż, kiedy 11 października 1896 roku Bruckner umarł, był jeszcze w trakcie pisania owej IX Symfonii, którą rozpoczął prawie 10 lat wcześniej. Czując się już nie najlepiej, miał przeczucie, że pisze swój „testament symfoniczny”, podobnie jak było w przypadku Beethovena i Schuberta. I rzeczywiście nie zdołał dokończyć czwartej części (tempo). W ocenie papieża „symfonizm Brucknerowski odróżnia się od modelu klasycznego; jego dyskurs muzyczny rozwija się bowiem przez wielkie

42 Zob. Przemówienie po koncercie ofiarowanym przez Fundację Muzyki i Sztuki Sakralnej, wykonanym przez Wiener Philharmoniker z okazji Synodu biskupów, bazylika św. Pawła za Murami, 13.10.2008, L'OR 12 (2008), s. 45n.

43 Zob. Przemówienie po koncercie ofiarowanym przez Bayerische Staatsoper, Aula Pawła VI, 22.10.2011. 
bryły (blocchi) zbliżone do siebie, przez sekcje wypracowane i kompleksowe, nieograniczone w sposób jasny, ale oddzielone bardzo często przez proste epizody spajające, jak też przez pauzy”. Kiedy słucha się jego muzyki, ma się wrażenie, jakby się było wewnątrz wielkiej katedry, że widzi się wielkie filary podtrzymujące jej architekturę, które porywają widza i kierują jego spojrzenie ku górze, wywołując wielkie emocje. Widać więc, że u podstaw twórczości Brucknera, tak symfonicznej, jak i sakralnej, stoi jego wiara, prosta, solidna i autentyczna, zachowywana w całym życiu do tego stopnia, że chciał, by go pochowano w kościele opackim Sankt Florian, w krypcie pod potężnymi organami, na których wielokrotnie grywał.

Gdy zaś chodzi o jego wiarę - powiedział papież - to porównując go z wielkimi przedstawicielami późnego romantyzmu, wielki dyrektor orkiestry Bruno Walter stwierdził: „Mahler zawsze był w trakcie poszukiwania Boga, podczas gdy Bruckner Go znalazł”. I może o tym świadczyć ta właśnie, wykonana symfonia, której precyzyjny tytuł brzmi: Dem lieben Gott (Dobremu Bogu). Tak, jakby chciał zadedykować i powierzyć ostatni owoc swej sztuki Temu, w którego zawsze wierzył, z którym naprawdę rozmawiał, do którego się zwracał przez całe życie, aż do ostatniego momentu. Kiedy ma się na uwadze jego wiarę, można lepiej zrozumieć znaczenie nieustannego oczekiwania, takty rozciągnięte, które otwierają słuchaczy i prowadzą do wymiaru tajemniczego, niemal bezczasowego; „od pierwszego taktu określonego wskazaniem Feierlich - misterioso aż do adagio, które rozpoczyna się partią pierwszych skrzypiec i rozwija się, wstępując progresywnie ku alto, zmienia się następnie w chwile świetnej (luminosi), nieoczekiwanej ciszy, potem w odosobnione sekcje głosowe, dźwięczność organów i chórów, wreszcie w eksplozję dźwięków pogodnych i śpiewnych (cantabili), aż do osiągnięcia spokojnego, powolnego, radosnego zakończenia w e-moll”. Znaczące wydaje się zwłaszcza, że w to ostatnie tempo zostały włączone cztery nuty z Miserere z Gloria z Missa in $d$-moll i są też zauważalne reminiscencje z Benedictus z jego Missa f-moll.

Bruckner prosił w ten sposób dobrego Boga, aby mógł uczestniczyć w Jego misterium, aby mógł wstąpić na Jego wysokości i chwalić w niebie Pana, tak jak to czynił dotychczas swą muzyką na ziemi. Wspaniałe dzieło, które wykonano pt. Te Deum laudamus, Te Dominum confitemur, zostało napisane za jednym zamachem i było przepracowywane przez piętnaście lat, jakby po to, by przemyśleć i jeszcze lepiej wyrazić wdzięczność i doskonalej uwielbić Boga; Te Dominum stanowi więc syntezę wiary wielkiego muzyka, powtórzone w wielkiej, podwójnej fudze końcowej. A słowa „In Te, Domine speravi, non confundar in aeternum” skierowane są również do słuchaczy, aby poszerzyli horyzonty swego widzenia i pomyśleli o życiu wiecznym, nie po to, by uciekać od rzeczywistości, pomimo iż jest naznaczona problemami i trudnościami, ale po to, by nią jeszcze intensywniej żyć, wnosząc w otaczającą rzeczywistość nieco światła, nadziei i miłości. 
Innym koncertem, ilustrującym religijny charakter kultury muzycznej Europy, był koncert wykonany z okazji 85 . urodzin papieża ${ }^{44}$ przez jedną z najstarszych i najsłynniejszych orkiestr świata, tzw. Gewandhausorchester z Lipska, która wykonała Symfonię N. 2 Lobgesang Felixa Mendelssohna-Bartholdy'ego. Jest ona wielkim hymnem uwielbienia Boga, modlitwą dziękczynną za Jego dary. Papież przypomniał przy tej okazji, że ta wielka symfonia na chór, solistów i orkiestrę została skomponowana na obchody czterechsetnej rocznicy wynalezienia druku i po raz pierwszy została wykonana w kościele św. Tomasza w Lipsku, czyli w kościele Johanna Sebastiana Bacha, w dniu 25 czerwca 1840 roku właśnie przez orkiestrę Gewandhaus, którą dyrygował przez wiele lat i także wówczas sam Mendelssohn.

Kompozycja ta składa się z trzech części (tre movimenti) dla samej orkiestry, pomiędzy którymi jest ciągłość, a potem następuje rodzaj kantaty z solistami i chórem. W liście do swego przyjaciela Karola Klingemanna sam kompozytor wyjaśniał, że w tej symfonii „najpierw wielbią Boga instrumenty, w sposób dla nich kongenialny, a potem chór i pojedyncze głosy”. Papież podkreślił następnie, że sztuka jako uwielbienie Boga, tj. najwyższego Piękna, stoi u podstaw sposobu komponowania Mendelssohna, i to nie tylko, gdy chodzi o muzykę liturgiczną lub sakralną, lecz o całość jego twórczości.

Jak pisze Julius Schubring, dla niego muzyka sakralna, jako taka, nie była jakimś wyższym stopniem w stosunku do innej, bo w gruncie rzeczy każda muzyka winna służyć uczczeniu Boga. A motto, które kompozytor umieścił na partyturze Symfonii Lobgesang, brzmi następująco: „Chciałbym widzieć wszystkie sztuki, zwłaszcza muzykę, w służbie Tego, który je dał i stworzył”. Może więc z tego wynikać, że świat etyczno-religijny nie był - dla niego - oderwany od jego sztuki, a wręcz przeciwnie, stanowił jej część integralną. Kompozytor pisał nawet, że sztuka i życie nie są dwiema rzeczami oddzielonymi, ale są czymś jednym („Kunst und Leben sind nich zweierlei”). Głęboka jedność życia znajdowała bowiem dla siebie czynnik jednoczący w wierze, charakteryzując całą egzystencję Mendelssohna i kierowała wszystkimi jego decyzjami. Potwierdza to jego list do przyjaciela Schirmera z 9 stycznia 1841 roku, gdzie pisał o swojej rodzinie: „Z pewnością nie brak niekiedy trosk i ciężkich dni, a jednak nie można niczego innego robić, jak tylko modlić się gorąco do Boga, aby podtrzymywał zdrowie i szczęście, jakiego udzielił”. Podobnie ujął to również w liście z 17 stycznia 1843 roku do wspominanego już wyżej, innego przyjaciela: „Nie mogę robić niczego innego, jak tylko dziękować Bogu na kolanach każdego dnia za wszelkie dobro, jakiego mi udziela”. A więc - jak skonkludował papież - wybijała się u tego artysty wiara silna i żarliwa,

\footnotetext{
44 Zob. Przemówienie po koncercie ofiarowanym przez orkiestrę Gewandhaus z Lipska z okazji 85. urodzin Ojca świętego, Aula Pawła VI, 20.04.2012.
} 
żywiona w sposób głęboki Pismem Świętym, jak to ukazują dwa oratoria Paulus i Elias oraz wykonana właśnie symfonia, pełna odniesień biblijnych, zwłaszcza do Psalmów i do św. Pawła.

Benedykt XVI zwrócił następnie uwagę na cudowny duet sopranów i chór, który wykonał słowa Psalmu 40: „Pokładam nadzieję w Panu, a On pochylił się nade mną i wysłuchał mego wołania”. Jest to śpiew kogoś, kto jest pewien, że nie zostanie zawiedziony. Papież przywołał też słowa Roberta Schumanna, który nazwał to dzieło Opera luminosa i po koncercie napisał: „Porzućmy dzieła ciemności i chwytajmy za bron światła", co można by rozumieć także w ten sposób, że wysłuchanie dzieła skłania do porzucenia zła i czynienia dobra.

\subsection{Wokót istoty muzyki kościelnej}

Okazję, by obszerniej wypowiedzieć się na temat istoty muzyki kościelnej, dał papieżowi koncert Wyższej Szkoły Katolickiej Muzyki Kościelnej z Ratyzbony ${ }^{45}$. Przypomniał on przede wszystkim, że szkoła powstała już w XIX wieku jako pierwsza taka szkoła, na której wzorowano się potem, powołując Papieski Instytut $\mathrm{Mu}$ zyki Sakralnej w Rzymie. Stworzono ją, kiedy następowało odrodzenie muzyki kościelnej i kiedy poszukiwano sposobu, jak ją odnowić, wychodząc od jej istoty. Od tamtego czasu wciąż zadawano sobie pytanie o istotę muzyki kościelnej i o właściwe jej wykonywanie. Nowy impuls nadał tym poszukiwaniom dopiero Sobór Watykański II. Chodziło bowiem o to, by muzyka sakralna nie była tylko ogólnie religijną muzyką, ale by rzeczywiście była muzyką Kościoła, tzn. by nie stanowiła jedynie jakiegoś dodatku do liturgii, ale była składnikiem liturgii samej ${ }^{46}$. Odpowiadając na to oczekiwanie, papież przypomniał motto św. Benedykta zaczerpnięte z jego reguły mniszej, które służyło za wytyczną dla śpiewu psalmów: „Coram angelis psallam tibi, Domine” („Wobec aniołów będę śpiewał Tobie, Panie”).

Benedykt XVI znajduje w tej wytycznej dwa warunki: pierwszy to Tibi-śpiewamy Tobie, Boże; czyli że poprzez śpiew dokonuje się spotkanie z żywym Bogiem. Wierni nie śpiewają przecież sami dla siebie, ale kierują swój śpiew ku górze, ku Tobie, Boże. Winni więc robić to tak gorliwie, aby ten śpiew do Niego dotarł. Śpiewają przecież dla Pana, dla Boga, który nie jest kimś nieznanym, ale który ma twarz, twarz Jezusa Chrystusa. Dla Boga, który jest Logosem, Słowem, Rozumem, Miłością. Chodziłoby zatem o muzykę, która jest z jednej strony rozjaśniona przez

\footnotetext{
45 Zob. Przemówienie do delegacji Wyższej Szkoły Katolickiej Muzyki Kościelnej w Ratyzbonie, Castel Gandolfo, 28.09.2007.

46 Sobór Watykański II, Konstytucja o liturgii świętej Sacrosanctum concilium [dalej: SC], 112, w: Sobór Watykański II, Konstytucje. Dekrety. Deklaracje, Poznań 2002.
} 
rozum, a jednocześnie ma swe źródło w sercu, czyli inspiruje ją miłość. Drugim z kolei warunkiem - jaki znajduje papież w wytycznej swego patrona - jest świadomość, że śpiew odbywa się coram angelis - czyli wobec aniołów. Benedyktyni a także wszyscy wierni - winni zatem pamiętać o tym, że ich chóralnemu śpiewowi towarzyszą w ciszy aniołowie, że wsłuchują się w ich śpiew i dlatego ten śpiew powinien być taki, by aniołowie mogli go słuchać. A zebrani na liturgii wierni też wraz z nimi śpiewają; toteż każdy powinien otworzyć „ucho” swego serca tak szeroko, aby w jego głębi usłyszeć ten anielski śpiew, włączyć się weń i razem z nimi śpiewać. Jednak śpiew odbywa się nie tylko wobec aniołów oraz z aniołami, ale także z całą wspólnotą świętych, wszystkich miejsc i czasów.

W ten sposób muzyka i śpiew nabierają wymiaru kosmiczno-eschatologicznego ${ }^{47}$. Wskazuje na to również fakt, że we Mszy św. są dwie pieśni zbudowane z tekstów biblijnych, które zostały zaśpiewane przez aniołów ${ }^{48}$ : hymn Gloria (Chwata na wysokości Bogu), zaśpiewane po raz pierwszy przez aniołów, gdy urodził się Jezus i trisagion Sanctus (Święty...), który według Księgi Izajasza 6, 3 jest inwokacją serafinów przebywających w bezpośredniej bliskości Boga. Śpiewanie w obecności zastępów chórów anielskich i świętych jest najwyższym kryterium modlitwy i śpiewu, tzn. trzeba je tak wykonywać, by się dołączyć do muzyki najwyższych duchów, uważanych za ważnych twórców harmonii kosmosu i muzyki niebiańskiej. W związku z tym kakofonia, czyli złe wykonanie śpiewu mnichów nie było - zdaniem św. Bernarda z Clairvaux - bagatelnym incydentem, lecz odejściem do regio dissimilitudinis - krainy, gdzie wszystko jest na opak. Zaś krainą na opak nazwał Augustyn swój stan przed nawróceniem, a więc stan grzechu, gdzie człowiek jest daleko od Boga, gdzie nie jest już odbiciem Boga, ale bytem niepodobnym do swego Stwórcy i do swej prawdziwej natury ludzkiej.

Papież zwrócił przy tej okazji uwagę, że - co prawda - słowo psallere oznacza tyle, co śpiewać, ale oznacza równocześnie, że temu „śpiewaniu” niejako z natury rzeczy towarzyszy jakiś instrument, czyli oznacza zarazem granie. Wierni zatem śpiewają i grają najpierw dla Ciebie - tj. dla jednego i wszechmocnego Boga w Trójcy Jedynego, ale śpiewają i grają nie jako pojedyncze osoby, lecz jako osoby włączone we współbrzmienie wielkiego śpiewu nieba i ziemi wszech czasów. Zainspirowani i poruszeni przez Boga, tj. przez Prawdę i Miłość, pozwalają porwać się temu wielkiemu śpiewaniu przez stulecia, zarówno śpiewaniu dawnych chórów, które już przeminęły, jak i tych, które w przyszłości się pojawią.

47 Por. T. Samulnik, Biblijne i systematyczne źródta teologii muzyki Josepha Ratzingeral Benedykta XVI, dz. cyt., s. 137-139.

48 Zob. Przemówienie do przedstawicieli świata kultury, Paryż, Collegium Bernardinum, 12.09.2008. 
Z podobnego rozumienia muzyki i śpiewu papież wyprowadził następnie zarówno zobowiązanie, jak i wolność dla muzyki kościelnej. Uznał bowiem, że istotą tej zależności jest nie tyle podporządkowanie się zewnętrznym przepisom czy przyjętym regułom, ile raczej fakt, że śpiewający zwracają się do Bożego Ty, że właśnie Jemu pozwalają się oświecać i oczyszczać, i w taki sposób włączają się w wielką symfonię tego My. Starają się przy tym uczestniczyć w owej symfonii w taki sposób, by nie zniszczyły jej żadne fałszywe tony, ale by ją jeszcze bardziej ubogacać i poszerzać. Ta szczególna i mocna więź jest jednak zarazem wolnością, gdyż śpiewają nie tylko z Kościołem przeszłości, lecz także z Kościołem przyszłości. Z tego właśnie względu zawsze potrzebne wydaje się spojrzenie twórcze i szerokie. Bo inspiracja, która pochodzi od Boskiego Ty, któremu śpiewają chóry, i jednocześnie od wspólnoty świętych, z którymi śpiewają, wcale nie ogranicza prawdziwej kreatywności, ale - wręcz przeciwnie - pobudza ją.

Takie właśnie założenia muzyki kościelnej realizowała szkoła muzyczna w Ratyzbonie; zawsze chciano tam wykonywać muzykę kościelną, tj. taką, która jest wielką muzyką przed Bogiem oraz która jest muzyką prawdziwą. Oczywiście żadnej muzyki nie powinno się nazywać muzyką kościelną, o ile nie należałaby do prawdziwie wielkiego dziedzictwa muzyki światowej. Zaś obowiązkiem szkoły muzycznej jest sprawianie młodym ludziom radości muzykowania dla Boga i w Kościele, by mogli w ten sposób dźwigać, niejako od wewnątrz, ciężar liturgicznego wydarzenia, jakim jest $\mathrm{w}$ istocie śpiew przed Bogiem i dla Boga ${ }^{49}$.

Niedługo po tym koncercie Benedykt XVI odwiedził Papieski Instytut Muzyki Sakralnej ${ }^{50}$, gdzie również poruszył zagadnienia związane z istotą muzyki kościelnej. Ponownie wyszedł od nauki Soboru Watykańskiego II, który idąc po linii świeckiej tradycji, stwierdził, że „stanowi ona skarbiec nieocenionej wartości, wyróżniający się wśród innych form wyrazu artystycznego, szczególnie tym, że śpiew kościelny, jako związany ze słowami, jest nieodzowną oraz integralną częścią uroczystej liturgii” (SC 112).

Papież zwrócił też uwagę na bogatą tradycję biblijną i patrystyczną, która poświadcza, że śpiew i muzyka sakralna skutecznie oddziałują na ludzkie serca, że je poruszają i pomagają im wznieść się ku Bogu i tym samym pozwalają im przeniknąć do samego wnętrza życia Boga. Przywołał także Jana Pawła II, który zauważył, że jak zawsze, tak i obecnie trzy cechy wyróżniają muzykę liturgiczną spośród innych form muzyki sakralnej, mianowicie: świętość, prawdziwy kunszt oraz

\footnotetext{
49 Zob. Przemówienie do delegacji Wyższej Szkoły Katolickiej Muzyki Kościelnej w Ratyzbonie, Castel Gandolfo, 28.09.2007.

50 Zob. Przemówienie w czasie wizyty w Papieskim Instytucie Muzyki Świętej w Rzymie, 13.10.2007.
} 
powszechność. Toteż - uznał - iż muzykę, która spełnia te trzy warunki, można by właściwie zaproponować każdemu narodowi czy każdemu rodzajowi zgromadzenia $^{51}$. Wymagałoby to jednak, by władze kościelne bardziej się w te sprawy angażowały, by mądrze ukierunkowywały rozwój tak szczególnego rodzaju muzyki, aby nie dopuścić do „zamrożenia” jej skarbca, ale by w całe dziedzictwo przeszłości włączać również wartościowe utwory współczesne i w ten sposób tworzyć syntezę, która byłaby godna wzniosłej misji, jaka została przewidziana dla muzyki w służbie Bożej. Jest to ogromne wyzwanie, ale też stanowiące wielką wartość dla samego życia Kościoła.

\subsection{Przez piękno do Boga}

Drogę piękna - via pulchritudinis - jako jedną z dróg prowadzących do Boga, przedstawił Jan Paweł II w katechezie uwspółcześniającej pięć dróg św. Tomasza (ekspansja wszechświata, doskonała organizacja w strukturze materii mikrokosmosu i makrokosmosu, wewnętrzna celowość w rozwoju życia, celowość w historii ludzkości i życiu pojedynczego człowieka, piękno natury i piękno dzieł sztuki, w tym także dzieł muzyki ${ }^{52}$ ). Badacze teologii Josepha Ratzingera wskazują na szeroko stosowaną przez niego drogę piękna jako prowadzącą do poznania i uwielbienia $\mathrm{Boga}^{53}$, tak że nazwano go promotorem viae pulchritudinis w dziele nowej ewangelizacji. Tę drogę papież nakreślił m.in. w przemówieniu do artystów ${ }^{54}$. Powiedział, że prawdziwe piękno manifestuje się we wszechświecie i w naturze, ale też wyraża się poprzez dzieła artystyczne. To piękno otwiera i poszerza horyzont ludzkiego poznania, odsyła ponad siebie, konfrontuje człowieka z głębią Nieskończoności i może stać się drogą ku Transcendencji, ku Misterium ostatecznemu, ku Bogu. Sztuka we wszystkich swych wyrazach, w chwilach kiedy się konfrontuje z wielkimi pytaniami egzystencjalnymi i fundamentalnymi dotyczącymi sensu życia, może przyjąć wartość religijną i służyć głębokiej refleksji duchowej. Teologia nazywa ją drogą piękna, a stanowi ją droga artystyczna, estetyczna, droga wiary i poszukiwań teologicznych.

Rolę drogi piękna spełniają ${ }^{55}$ rzeźby, obrazy, poezja, a także utwory muzyczne. Potrafią one bowiem głęboko wzruszać i budzić radość, a ta ostatnia, tj. muzyka, pozwala ponadto doświadczyć, że nie jest jakąś zwykłą kumulacją dźwięków, ale

\footnotetext{
51 Por. Jan Paweł II, Chirograf Mosso dal vivo desiderio z 22.11.2003.

52 Por. Jan Paweł II, Wierzę w Boga Ojca Stworzyciela, Città del Vaticano 1987, s. 112-115.

53 Por. R. Tyrała, Benedykt XVI doktorem ,honoris causa”..., dz. cyt., s. 9-37.

54 Zob. Przemówienie na spotkaniu z artystami, Kaplica Sykstyńska, 21.11.2009.

55 Zob. Katecheza w czasie audiencji generalnej, Castel Gandolfo, 31.08.2011.
} 
czymś znacznie więcej, tj. czymś, co w swoisty sposób „przemawia”, potrafi niejako „dotknąć” ludzkiego serca, przekazać treść jakiegoś orędzia i tym samym wprawić ducha w uniesienie.

Dzieło sztuki jest zawsze owocem zdolności kreatywnych człowieka, który obserwując widzialną rzeczywistość, stara się odkryć jej głębszy sens i przekazuje go przy pomocy języka form, kolorów czy dźwięków. Sztuka jest bowiem w stanie wyrazić i zrealizować ludzką potrzebę wyjścia poza to, co widzialne; objawia pragnienie i poszukiwanie nieskończoności, a nawet więcej, bo jest jakby otwartymi drzwiami ku nieskończoności, ku pięknu i prawdzie, które zwykle wyrastają ponad sprawy codzienne. Dzieło sztuki może więc w pewnym sensie otwierać oczy umysłu i serca, i zachęcać do dążenia wzwyż.

Jest chyba wiele dzieł artystycznych, które stanowią prawdziwe ścieżki ku Bogu, ku najwyższemu Pięknu i które mogą służyć pomocą we wzrastaniu w więzi z Bogiem na modlitwie. Podobne dzieła rodzą się z wiary i wyrażają wiarę. Słuchając utworu muzycznego o charakterze sakralnym, człowiek może nawet odczuwać, że jego serce bije szybciej, a jego dusza jakby poszerza się i uskrzydla, by wznosić się ku Bogu. Toteż na koniec papież zachęcił do odkrywania, że ta droga jest naprawdę doniosła, także dla modlitwy oraz dla ożywienia i umocnienia więzi i dia$\operatorname{logu} \mathrm{z}$ Bogiem.

\subsection{Muzyka i śpiew prowadzą do nawrócenia i wiary}

Dziękując za wykonanie Oratorium ${ }^{56}$, będącego muzyczną opowieścią o dziejach życia św. Augustyna (IV-V w.), papież zauważył, że podobne koleje ludzkich losów zdarzają się i współcześnie. Walka człowieka i jego nieustanne próby docierania do własnej głębi, w poszukiwaniu prawdy i w poszukiwaniu Boga, będą się bowiem toczyły po wszystkie czasy. Gdy zaś chodzi o nawrócenie Augustyna, to przyzwyczailiśmy się uważać, że dokonało się ono pod wpływem lektury Pisma Świętego: „Bierz i czytaj”. Benedykt XVI ${ }^{57}$ zwrócił jednak uwagę na to, że do jego nawrócenia walnie przyczynił się również śpiew psalmów i hymnów wykonywanych w czasie liturgii w katedrze mediolańskiej, której przewodniczył wtedy św. Ambroży. Jeśli bowiem wiara rodzi się ze słuchania słowa Bożego, to oczywiście nie tylko w sensie dosłownego usłyszenia tego słowa, co zapewniają zwykle uszy; chodzi raczej o takie słuchanie, które zaczyna się - co prawda - w zmysłach, ale

\footnotetext{
56 Zob. Przemówienie po wykonaniu oratorium Augustinus - un mosaico di suoni ofiarowanego przez diecezję Würzburg, Castel Gandolfo, 26.09.2012.

57 Zob. Przemówienie do uczestników spotkania zorganizowanego przez Włoskie Stowarzyszenie Świętej Cecylii, Aula Pawła VI, 10.11.2012.
} 
następnie przenika umysł i serce. Nie ma zatem wątpliwości, że muzyka, a nade wszystko śpiew, mogą nadawać recytacji psalmów i kantyków biblijnych większą moc przekonywania. Taką właśnie mocą odznaczały się muzyka i śpiew wykonywane pod patronatem św. Ambrożego. Wśród wielu zdolności posiadał on bowiem wybitną wrażliwość i zdolności muzyczne, a jako biskup Mediolanu oddał je wszystkie na służbę wiary i ewangelizacji.

Wpływ hymnów ambrozjańskich okazał się w przypadku Augustyna tak silny, że wryły mu się na zawsze w pamięć i potem często cytował je w swoich dziełach. Co więcej, napisał nawet dzieło poświęcone muzyce: De Musica. Stwierdza tam, że choć akceptuje poszukiwanie samej przyjemności zmysłowej w czasie liturgii śpiewanych, to jednak uważa, że dobrze wykonane muzyka i śpiew mogą także pomóc w przyjęciu słowa Bożego przez dokonanie zbawczego wzruszenia.

Papież przytoczył inny jeszcze przykład wielkiej konwersji, która dokonała się pod wpływem muzyki i śpiewu, mianowicie przypadek francuskiego poety - Paula Claudela, który w 1886 roku wszedł do katedry Notre Dame w Paryżu, by zebrać argumenty przeciwko chrześcijanom, ale słuchając śpiewu Magnificat podczas nieszporów bożonarodzeniowych, doświadczył obecności Boga, który swą łaską dokonał jego nawrócenia. „W jednej chwili - pisze - wydarzyło się coś, co zdominowało całe moje życie. Wtedy moje serce zostało dotknięte, poruszone i uwierzyłem. Uwierzyłem z tak wielką mocą przylgnięcia do Boga, z takim uniesieniem całego mojego jestestwa, z tak silnym przekonaniem, z taką pewnością, która nie pozostawiła żadnej wątpliwości, że od tamtego czasu żadne rozumowanie, żadna okoliczność mego życia nie mogły wstrząsnąć moją wiarą ani jej zachwiać” ${ }^{58}$.

\subsection{Muzyka i śpiew uwydatniają doniosłość wydarzeń zbawczych}

W okresie Bożego Narodzenia 2005 roku papież przyjął chór Pueri Cantores i słuchając pieśni związanych z tajemnicą wcielenia, podkreślit ${ }^{59}$, że w tym czasie trzeba śpiewać na chwałę Pana i wyrażać Mu swą radość, idąc za przykładem Maryi Dziewicy, która jako pierwsza wyraziła Bogu wdzięczność za tę tajemnicę swoim Magnificat, a Kościół podejmuje je z pokolenia na pokolenie. Śpiew świadczy bowiem o tym, że w ludziach wierzących jest radość, że Zbawiciel narodził się dla ludzi, że przyszedł, aby ich wyzwolić i zaprosić do wejścia z Nim do chwały niebieskiej.

Po wykonaniu oratorium, które zostało ofiarowane papieżowi przez Konferencję Episkopatu Włoch z okazji jego 80. urodzin, Benedykt XVI znalazł okazję, aby

\footnotetext{
58 Przemówienie do uczestników spotkania zorganizowanego przez Włoskie Stowarzyszenie Świętej Cecylii, Aula Pawła VI, 10.11.2012.

59 Por. Przemówienie do uczestników Kongresu Międzynarodowego Pueri Cantores, 30.12.2005.
} 
w sposób szczególny podkreślić rolę muzyki uwydatniającej tajemnicę paschalnąa ${ }^{60}$. Oratorium przywoływało bowiem osoby i sceny Ewangelii, które zwykle prowadzą ludzi wierzących do centralnego misterium wiary, jakim jest zmartwychwstanie Chrystusa. Papież przypomniał tytuł tego pięknego oratorium, które pozwoliło zasmakować kompozycji koncertowej i poetyckiej, zharmonizowanej dzięki splotowi ekspresywności melodii i symboliki religijnej. A tytuł ten brzmiał: Resurrexi (Zmartwychwstatem) i został wzięty z antyfony na wejście Mszy paschalnej. Sprawiał przy tym wrażenie autoprezentacji Jezusa, który w liturgii potwierdza swoją tożsamość i pozwala się rozpoznać jako zmartwychwstały Pan.

Wykonanie oratorium pozwoliło - zdaniem Benedykta XVI - ożywić uczucia zadziwienia i radości, jakich doświadczyli pierwsi naoczni świadkowie zmartwychwstałego Mistrza. Przy pomocy pięciu „obrazów” harmonijnie połączonych w splot melodyjno-poetycki autorzy tego dramatu pomogli słuchaczom w medytowaniu nad brzaskiem Trzeciego dnia, bogatego w olśniewające światło, które otwarło serca apostołów i pozwoliło im w pełni zrozumieć znaczenie dramatycznych wydarzeń, tj. śmierci i zmartwychwstania boskiego Mistrza, jak też znaczenie Jego gestów i słów poprzedzających te wydarzenia.

Następnie papież przypomniał, że Pascha jest w istocie sercem chrześcijaństwa. W tej tajemnicy paschalnej Chrystusa ochrzczeni biorą już udział w nowym życiu zmartwychwstałego świata. Toteż dla każdego człowieka i dla każdej wspólnoty kościelnej spotkanie z Chrystusem ukrzyżowanym i zmartwychwstałym jest oczywiście bardzo ważne. Bowiem bez tego doświadczenia zarówno osobistego, jak i wspólnotowego, tj. bez osobistej przyjaźni z Jezusem, wiara musi zawsze pozostać powierzchowna i sterylna. Bez takiej naprawdę głębokiej i mocnej wiary nie wydaje się też możliwe dawanie świadectwa ewangelicznego przez gorliwy zapał apostolski.

Po koncercie ofiarowanym Benedyktowi XVI przez prezydenta Włoch z okazji 6. rocznicy pontyfikatu ${ }^{61}$, podczas którego wykonano dwa arcydzieła Antonia Vivaldiego i Gioacchina Rossiniego, czyli dwóch znakomitych kompozytorów włoskich, przynoszących państwu włoskiemu trwałą chwałę, papież omówił pokrótce te dwa utwory. Zaznaczył, że Vivaldi jest przedstawicielem osiemnastowiecznej kultury weneckiej. Wyraził też zadowolenie z wykonania jego dzieła powstałego w 1715 roku, a zatytułowanego Credo, przynależnego do jego mało znanej twórczości sakralnej. Zwrócił też uwagę na niezwykły fakt, że w tej kompozycji wokalnej w ogóle brak partii solowych, a występuje jedynie chór, co - według niego - nie

60 Zob. Przemówienie z okazji wykonania oratorium ofiarowanego przez Konferencję Episkopatu Włoch z okazji 80. urodzin Benedykta XVI, 23.05.2007.

${ }_{61}$ Zob. Przemówienie po koncercie Opery Rzymskiej ofiarowanym przez prezydenta Włoch z okazji 6. rocznicy pontyfikatu, Aula Pawła VI, 5.05.2011, L'OR 7 (2011), s. 21-22. 
jest przypadkiem, lecz zostało świadomie zamierzone przez kompozytora. Postanowił on bowiem w ten sposób wyrazić pewne „my” wiary Kościoła, który jest przecież wspólnotą ludzi wierzących, a ludzie ci wyśpiewują swoją wiarę w różnych miejscach i różnych okresach dziejów. Pomimo iż wydaje się konieczne, by każdy wierzący wypowiadał osobiście swoje Credo - „wierzę”, to jednak wyznanie wiary pojedynczych osób zawsze wpisuje się w pewne „my” całej wspólnoty - powiedział papież. I dalej zwrócił uwagę na dwa zachwycające obrazy ze środkowej części dzieła: Et incarnatus est oraz Crucifixus. Poprzez powtarzanie słów i ciąłłe modulacje wyrażają one głębokie poczucie zdumienia w obliczu tajemnicy wcielenia i ukrzyżowania i skłaniają do refleksji oraz do modlitwy. W ten sposób Vivaldi zatrzymuje się na chwili, w której Bóg, choć wydawał się daleki, przyjmując ludzkie ciało, staje się bliski. Aby lepiej zilustrować postawę głębokiej wiary Vivaldiego, papież przytoczył jeszcze słowa Carla Goldoniego, przedstawiciela teatru weneckiego, który o swym pierwszym spotkaniu z kompozytorem napisał: „Zastałem go wśród muzyki, z brewiarzem w ręku”. Vivaldi był bowiem kapłanem, a jego muzyka zrodziła się z wiary.

Innym dziełem wykonanym w ramach tego koncertu, które skłoniło Benedykta do wielkiej medytacji nad tajemnicą śmierci Jezusa i nad głębokim bólem Maryi, było arcydzieło Rossiniego pt. Stabat Mater. Papież zwrócił przede wszystkim uwagę na okoliczności powstania tego dzieła. Otóż Rossini w wieku zaledwie 37 lat, w 1829 roku, zakończył swą twórczość operową - ostatnią operą Wilhelm Tell. Zaniechał już potem tworzenia dużych form muzycznych, poza dwoma wyjątkami, które są właśnie dziełami sakralnymi: Stabat Mater i Mata Msza uroczysta. Oba te dzieła pokazują, że religijność Rossiniego charakteryzuje się bogatą skalą uczuć w obliczu tajemnicy Chrystusa i silnym napięciem emocjonalnym: „Od pełnego bólu i czułości wielkiego fresku w pierwszej części Stabat Mater, po fragmenty, w których wybija się typowa dla Rossiniego włoska melodyjność, zawsze jednak pełna dramatyzmu, aż do końcowej podwójnej fugi z potężnym Amen, wyrażającym niewzruszoną wiarę, i In sempiterna saecula, które zdaje się chcieć dać poczucie wieczności”. Jednak zdaniem papieża, „prawdziwymi perełkami tego dzieła są dwa fragmenty a capella: Eja mater fons amoris oraz Quando Corpus morietur. Mistrz wraca w nich do lekcji wielkiej polifonii z intensywnością uczuć, która sprawia, iż stają się one przejmującą modlitwą: „Kiedy umrze moje ciało, spraw, by ma dusza została obdarzona chwałą raju". Po skomponowaniu Małej Mszy uroczystej Rossini w wieku 71 lat napisał: „Dobry Boże, oto ukończyłem tę biedną małą Mszę... Dobrze wiesz, że urodziłem się dla opery buffa! Trochę umiejętności, trochę serca, to wszystko. Bądź więc błogosławiony i przyjmij mnie do raju”. Ta prosta i szczera wiara kompozytora winna prowadzić do refleksji i podbudowywać wiarę słuchaczy - podsumował papież. 


\section{7. Śpiew wyrazem miłości do stworzeń i Stwórcy}

Piękny koncert chórów góralskich - prezentujący wspaniale wielką kulturę muzyczną tego regionu - ofiarowany papieżowi przez diecezję Belluno-Feltre ${ }^{62}$ przypomniał papieżowi słynne powiedzenie św. Augustyna, że cantare amantis estźródłem śpiewania jest miłość; tak, śpiew jest wyrazem miłości. Właśnie w śpiewie tych chórów dostrzegł wielką miłość mieszkańców dla pięknej ziemi dolomickiej ziemi stworzonej przez Boga. Zaś we wdzięczności i miłości do ziemi rozbrzmiewa miłość do Stwórcy, który obdarował swe dzieci ziemią, życiem radosnym, radością, którą można dostrzec jeszcze wyraźniej w świetle wiary, dającej świadectwo, że Bóg odnosi się do nich z wielką miłością. Papież nie omieszkał też podkreślić, że kultura ludowa, która prezentuje się tak wzniośle, jest prawdziwym klejnotem tożsamości europejskiej, należy więc ją kultywować i promować i za to trzeba być wdzięcznym tym, którzy to czynią.

Przemawiając po koncercie tzw. Serata Bavarese ${ }^{63}$, scharakteryzował kulturę bawarską jako kulturę radosną. Bierze się to stąd, że ludność żyje tu w harmonii ze stworzeniem, a przez to w harmonii z samym Stwórca, a ta z kolei sprawia, że dobrze jest być człowiekiem - osobą ludzką. Zapewne ułatwił to zadanie Bóg, ofiarując Bawarii świat niezwykle piękny, przepiękną ziemię, co pomaga w uznaniu, że jest On dobry i z tego powodu ułatwia bycie szczęśliwym. Ale Bóg sprawił też, że żyjący tu ludzie, akceptując swą sytuację mocną wiarą, potrafili nadać tej ziemi szczególne piękno; i dzięki tej kulturze osób, dzięki ich wierze, ich radosnym śpiewom, muzyce i sztuce, ta ziemia stała się niemal tak piękna, jak sam Stwórca. Co więcej, Bóg nie chciał uczynić tego wszystkiego sam; chciał działać przy pomocy ludzi. Ktoś jednak mógłby taką postawę podać w wątpliwość, pytając, czy mamy prawo być radośni i szczęśliwi, kiedy świat jest pełen cierpienia, kiedy istnieje tyle cierpienia i zła? Papież nie miał jednak tych wątpliwości i stwierdził, że jest to oczywiście uprawnione, ponieważ mówiąc „nie” radości, nie wyświadczamy nikomu przysługi, ale co najwyżej czynimy świat jeszcze bardziej ciemnym i smutnym. Kto zaś nie miłuje samego siebie, nie jest też w stanie dać drugiemu czegokolwiek, nie może mu ani pomagać, ani być heroldem pokoju. Mówi o tym wiara i nasze codzienne doświadczenie. Świat jest piękny i Bóg jest dobry. Jako taki Bóg stał się człowiekiem i przyszedł na ziemię, aby zamieszkać pośród ludzi. Cierpi i żyje z ludźmi, a ludzie wierzący wiedzą definitywnie i konkretnie, że Bóg

62 Zob. Przemówienie po koncercie chórów góralskich ofiarowanym przez diecezję Belluno-Feltre, Lorenzago di Cadore, 20.07.2007.

${ }^{63}$ Zob. Przemówienie po koncercie Serata Bavarese ku czci papieża, wykonanym w ramach pielgrzymki archidiecezji Monachium i Freising do Rzymu. Castel Gandolfo, 3.08.2012. 
jest dobry i że dobrze być człowiekiem. Po prostu wypada więc przeżywać tę radość i wychodząc od tej radości, nieść ją innym, odsuwać zło i być sługą pojednania i pokoju.

Benedykt XVI zwrócił jeszcze przy innej okazji uwagę na możliwości muzyczne zakodowane w instrumentach. Był zafascynowany zwłaszcza dźwiękiem oboju, na którym grał po mistrzowsku jeden z muzyków ${ }^{64}$. Było to - dla niego - niezwykle poruszające usłyszeć, jak z kawałka drewna, z którego zrobiony był instrument, wywodzi się cały wszechświat muzyki: niezgłębiony i radosny, poważny i zabawny, wielki i pokorny, wewnętrzny dialog melodii. Podkreślił nawet, że może to oznaczać, iż całe stworzenie jest przepełnione wielkimi możliwościami i że człowiek otrzymuje dar poznawania księgi świata i wydobywania na światło dzienne tych niezwykłych możliwości, co mu z pewnością pomaga w odzyskiwaniu energii nie tylko fizycznej, ale i duchowej.

\subsection{Muzyka i śpiew potęgują żar modlitwy do Boga}

W czasie koncertu, który prezydent Węgier ofiarował Benedyktowi z okazji 200-lecia narodzin Ferenca Liszta - jednego z największych pianistów wszechczasów i genialnego kompozytora nie tylko muzyki fortepianowej, ale i symfonicznej i sakralnej - został wykonany Psalm $13^{65}$. Po tym wykonaniu papież przypomniał, że kompozycja muzyki do tego psalmu powstała w latach, w których Liszt przebywał w Tivoli i Rzymie, a więc w czasie, kiedy niezwykle intensywnie przeżywał swoją wiarę (otrzymał nawet wówczas niższe święcenia) i tworzył wyłącznie muzykę sakralną. Wykonane podczas koncertu dzieło ukazało niezwykłą jakość i głębię owej wiary. Modlący się biblijnym psalmem znalazł się w trudnej sytuacji: osacza go nieprzyjaciel, a Bóg, jakby o nim zapomniał, jakby był nieobecny. Jego modlitwa przeradza się więc w wołanie udręczonego, który czuje się opuszczony i pozostawiony samemu sobie: „Dokąd, Panie?” - powtarza czterokrotnie psalmista, a tenor i chór w dziele Liszta powtarzają to, jakby walili młotem: „Dokąd, Panie?”. W ten sposób muzyka Liszta pozwala poniekąd słuchaczowi na odczucie owego ciężaru i udręki, jakie przeżywa ten, który się modli. Jednak Bóg nie opuszcza i nie porzuca. Psalmista dobrze o tym wie i jako człowiek wierzący wie także Liszt. Dlatego jego udręka przemienia się stopniowo w pełne ufności błaganie, a z kolei

${ }^{64}$ Zob. Przemówienie po koncercie ku czci papieża ofiarowanym przez Bayerisches Kammerorchester Bad Brücknau, Castel Gandolfo, 2.08.2009.

${ }_{65}$ Zob. Przemówienie po koncercie ofiarowanym przez prezydenta Republiki Węgier Pála Schmitta z okazji węgierskiej prezydencji w Radzie Unii Europejskiej oraz w 200. rocznicę urodzin Ferenca Liszta, Aula Pawła VI, 27.05.2011. 
błaganie staje się ostatecznie radością: „Niech się cieszy me serce z Twojej pomocy, chcę śpiewać Panu, który obdarzył mnie dobrem” (Ps 13, 6).

Następnie, w tym właśnie miejscu muzyka Liszta wyraźnie się zmienia: tenor, chór i orkiestra wznoszą hymn pełen zaufania, zawierzenia Bogu, Temu, który nigdy nie zdradza, nie zapomina, nigdy nie pozostawia człowieka samemu sobie. Liszt o swej Missa solemnis napisał: „Mogę naprawdę powiedzieć, że bardziej przemodliłem tę Mszę, aniżeli ją skomponowałem” i właściwie to samo można by powiedzieć o jego muzyce do Psalmu 13. Bowiem wielki muzyk węgierski bardziej przemodlił ów psalm niż go skomponował, lub też najpierw modlił się jego słowami, zanim go skomponował. Nic więc dziwnego, że muzyka do psalmu zaprasza - w gruncie rzeczy - abyśmy wznosili się do Boga na wysokości.

\subsection{Muzyka sakralna}

Czym charakteryzuje się muzyka sakralna? Na ten temat Joseph Ratzinger wypowiadał się wielokrotnie w swych publikacjach książkowych, brał udział w dyskusji posoborowej, polemizował z niewłaściwym jej pojmowaniem, wskazywał kierunki jej rozwoju ${ }^{66}$. Nic więc dziwnego, że jako papież mówił o tym wielokrotnie. I tak po koncercie z okazji 60-lecia kapłaństwa papieża i jego brata Georga, zatytułowanym Co czyni Bóg, jest dobre ${ }^{67}$, powiedział, że wykonano właśnie muzykę dwóch wielkich przedstawicieli XVIII wieku: Antonia Vivaldiego i Johanna Sebastiana Bacha - mistrzów nad mistrzami. Dwa wykonane utwory Vivaldiego to część tzw. Concerti ripieni, napisanych na orkiestrę smyczkową i bas cyfrowany (czyli niezależny głos basowy, realizujący podstawę harmoniczną utworu); ich duża część miała przede wszystkim cel dydaktyczny, zwłaszcza kiedy Vivaldi uczył w Pietà, tj. w jednym z czterech sierocińców znajdujących się w Wenecji, bardzo uzdolnione muzycznie dziewczęta. Papież nadmienił przy tym, że „Struktura trzech rodzajów tempa z krótkim adagio centralnym jest typowa dla tego wielkiego kompozytora, ale ta jednolitość architektoniczna nie pozostaje nigdy monotonna, ponieważ - jak to było słychać podczas wykonania - traktowanie brzmieniowe, barwa (colore) orkiestralna, dynamika mowy (discorso) muzycznej, mieszanki (impasti) harmonijne, sztuka harmonijnego przeplatana się stylów (contra punto) i naśladowania sprawiają, że koncerty

66 Por. J. Bramorski, Teologiczno-estetyczne wyznaczniki sakralności dzieta muzycznego, „Pro Musica Sacra” 11 (2013), s. 11-22; K. Kurnik, Muzyka czy „piosneczki tatwe i modne”? Spojrzenie na muzyczna sztukę w liturgii w oparciu o wybrane wypowiedzi Josepha Ratzingera - Benedykta XVI, „Pro Musica Sacra” 13 (2015), s. 71-84; T. Samulnik, Biblijne i systematyczne źródta teologii muzyki Josepha Ratzingera/Benedykta XVI, dz. cyt., s. 127-142.

${ }^{67}$ Zob. Przemówienie po koncercie ofiarowanym przez Ensemble „New Seasons” ku czci papieża i brata, prałata Georga Ratzingera, z okazji 60. rocznicy kapłaństwa, 9.08.2011. 
Vivaldiego są przykładem świetlistości (luminosità) i piękna oraz przekazują pogodę ducha i radość”. Papież wyraził też przekonanie, że źródłem tej radości może być również wiara kompozytora. Vivaldi był bowiem katolickim kapłanem, wiernym swemu brewiarzowi i przywiązanym do pobożnościowych praktyk. Dlatego słuchanie muzyki sakralnej, którą tworzył, ujawnia zarazem głęboką religijność jego duszy.

Owa religijność sylwetki - jak zauważył Benedykt XVI - łączy w pewien sposób katolickiego księdza Vivaldiego z luteraninem - Johannem Sebastianem Bachem, który tak bardzo podziwiał Vivaldiego, że studiował jego dzieła i przepisywał nawet niektóre jego koncerty. Swą wiarę wyrażał zaś słowami: Soli Deo gloria i słowa te pojawiają się jak refren w licznych manuskryptach Bacha, zwłaszcza jako Leitmotiv jego kantat; stanowią zatem element centralny dla zrozumienia muzyki tego wielkiego, niemieckiego kompozytora. Bo - zdaniem papieża - głęboka pobożność była istotnym elementem jego charakteru, a jego mocna wiara podtrzymywała i oświecała całe jego życie. Na okładce dzieła Kleines Orgelbüchlein można nawet odczytać dwa wersy, które Bach tam umieścit: „Dem chöchsten Gott allein zu ehren, dem Nächsten draus sich zu belehren”, tj. „Dla uczczenia najwyższego Boga i dla pouczenia bliźniego".

Jak z tego wynika, Bach rzeczywiście miał głęboko religijną koncepcję sztuki. Był przekonany, że jej głównym zadaniem jest oddawać cześć Bogu i odnawiać serce człowieka. Toteż słuchając jego muzyki, mamy wrażenie, jakby płynął strumyk, czy raczej jakby ukazywała się nam wielka konstrukcja architektoniczna, w której wszystko jest harmonijnie powiązane, jakby artysta próbował odtworzyć tę doskonałą harmonię, jaką Bóg opieczętował swoje stworzenie. „Bach jest wspaniałym architektem muzyki - podkreślił papież - z niezrównanym użyciem kontrapunktu, przeciwstawiającym style, architektem kierującym się silnym ésprit de géometrie, symbolem porządku i mądrości, odbiciem Boga i dzięki temu czysta racjonalność staje się - u niego - muzyką w sensie bardziej wzniosłym i czystym, jaśniejącym wprost pięknem. Znakomicie wykonany koncert pozwolił podziwiać tego szczególnego ducha Bacha, zwłaszcza w jego wczesnych pracach, wziętych z monumentalnego dzieła wiary, jakimi są Kantaty, w których jest muzyka czystej, krystalicznej Partity n. 2 d-moll, a także ten bardzo piękny Koncert na obój i skrzypce BWV 1060, zaproponowany w wersji, która prawdopodobnie odpowiada tej najstarszej" ${ }^{68}$.

Po koncercie wykonanym pod dyrekcją kard. Domenica Bartolucciego ${ }^{69}$ papież powiedział, że słuchacze mogli zanurzyć się w muzyce sakralnej, tej muzyce,

68 Przemówienie po koncercie ofiarowanym przez Ensemble „New Seasons” ku czci papieża i brata, prałata Georga Ratzingera, z okazji 60. rocznicy kapłaństwa, 9.08.2011.

${ }_{69}$ Por. Przemówienie z okazji koncertu ofiarowanego przez kard. Domenica Bartolucciego, Castel Gandolfo, 31.08.2011. 
która w sposób szczególny rodzi się z wiary i jest zdolna wiarę wyrażać i przekazywać. Toteż dla Kardynała muzyka jest uprzywilejowanym językiem przekazu wiary Kościoła i pomaga tym, którzy jej słuchają, kroczyć w życiu drogą wiary. Podkreślił, że właśnie poprzez muzykę, Kardynał pełni swą kapłańską posługę. Także tego wieczoru, wraz z chórem, ofiarował słuchaczom chwile medytacji i modlitwy, pomagając im pośród codziennych zajęć odczuć harmonię nieba. Dlatego sposób jego komponowania włącza się w pasmo wielkich autorów muzyki sakralnej, związanych zwłaszcza z Kaplicą Sykstyńską, gdzie przez wiele lat był dyrektorem. Benedykt XVI zaznaczył, że zawsze umiał on doceniać niezwykły skarb, jakim jest śpiew gregoriański i mądre stosowanie zarówno wiernej tradycji polifonii, jak też otwartej na nowe dźwięki muzyki. Wykonanymi utworami pozwolił słuchaczom skierować swe dusze przez modlitwę ku Maryi, która jest tradycji chrześcijańskiej najdroższa. Dzięki innym utworom sprawił także, że mogli powrócić do początków wiary, do liturgii chrztu, tj. do chwili, gdy stawali się chrześcijanami, kiedy to wspólnota zapraszała ich do zaspokajania pragnienia jedyną wodą, która naprawdę je gasi, a ma ją tylko sam żywy Bóg, i do zaangażowania się każdego dnia w odrzucanie zła i odnawianie swej wiary, podobnie jak Kardynał, którego charakterystyczne motto, przyświecające całemu jego życiu, muzyce i posłudze brzmi: "Chrystus mnie urzekł i porywa mnie”.

Dziękując chórowi Domspatzen, który wykonywał pieśni religijne w pięknej scenerii Kaplicy Sykstyńskiej, papież podkreślił70, że wszystkie te dzieła zrodziły się z inspiracji wiary, co więcej, że prowadzą one do wiary i modlitwy, a wykonana w tej scenerii muzyka budzi w ludziach radość z obcowania z Bogiem ${ }^{71}$. Zwrócił też uwagę na wykonany Psalm 84, zwłaszcza na - modlącego się tym psalmem - jego autora. Czuje się on bowiem wróblem, który znalazł sobie ulubione miejsce przy ołtarzach Boga, miejsce, gdzie może przebywać i czuć się „szczęśliwym”. Jest to obraz bardzo radosny, za pomocą którego psalmista próbuje właściwie powiedzieć, że całe jego życie stało się dzięki temu śpiewem. Wróbel może przecież i śpiewać i fruwać; ale już samo śpiewanie jest dla niego fruwaniem, czyli wznoszeniem się ku Bogu, a także w jakiś sposób zapoczątkowaniem uczestniczenia w wieczności, kiedy to zbawieni będą mogli „nieustannie śpiewać chwałę Bogu”. Na koniec Benedykt XVI raz jeszcze podkreślił, że ów psalm w sposób szczególny kieruje na to

\footnotetext{
70 Zob. Przemówienie na zakończenie koncertu wykonanego ku czci papieża przez Regensburger Domspatzen - chór katedry w Ratyzbonie, Kaplica Sykstyńska, 22.10.2005.

71 Warto dodać, że kiedy indziej papież podkreślił, iż cała symfonia figur w Kaplicy Sykstyńskiej nabiera życia w czasie akcji liturgicznej, której towarzyszy muzyka i śpiew. Por. Przemówienie w czasie pierwszych nieszporów z okazji 500. rocznicy odsłonięcia malowideł w Kaplicy Sykstyńskiej, 31.10.2012.
} 
wszystko uwagę słuchaczy. Życzył zarazem chórowi, by zawsze był ambasadorem piękna, wiary, ambasadorem Boga i by w centrum swojej posługi stawiał służbę ku Bożej chwale.

Z kolei z okazji 7. rocznicy pontyfikatu prezydent Włoch ofiarował papieżowi koncert wykonany przez orkiestrę i chór Teatru Operowego w Rzymie, pod kierunkiem dyrygenta, który jest znany ze szczególnej wrażliwości na muzykę sakralną i z zaangażowania w upowszechnianie bogatego repertuaru wyrażającego muzycznie wiarę Kościoła ${ }^{72}$. Zostały wówczas wykonane dzieła Antonia Vivaldiego, przedstawiciela muzyki weneckiej, znanego powszechnie przede wszystkim ze względu na jego Quattro Stagioni (Cztery pory roku), ale już mniej znanego z tworzenia muzyki sakralnej, która zajmuje przecież znaczące miejsce w jego dorobku i ma przy tym wielką wartość, jako że wyraża jego wiarę. Wykonano Magnificat-śpiew uwielbienia Maryi i wszystkich pokornych sercem, którzy rozpoznają i z radością oraz wdzięcznością świętują działanie Boga w swym życiu i w historii, działanie Boga, którego „styl” jest zupełnie inny od stylu człowieka, ponieważ Bóg wstawia się zwykle za tymi „ostatnimi”, wlewając w ich serca nadzieję.

Muzyka Vivaldiego wyraża właśnie owo uwielbienie, radość i dziękczynienie, a także „podziw dla dzieła Bożego poprzez niezwykłe bogactwo uczuć: od uroczystego śpiewu chóralnego na początku, który wyraża cały uwielbiający Pana Kościól, poprzez pełen werwy Et exultavit, przepiękny śpiew chóru Et misericordia, na którym zatrzymuje się ze śmiałymi harmoniami, bogatymi w niespodziewane modulacje", aby zaprosić słuchaczy do medytowania nad miłosierdziem Boga, który jest wierny i rozciaga to miłosierdzie na wszystkie pokolenia.

Następnie zostały wykonane dwa utwory sakralne Giuseppe Verdiego, w których charakter w skali głosu się zmienił. Wybrzmiała bowiem Stabat Mater dolorosa, która to pieśń postawiła słuchaczy w obliczu bólu Maryi stojącej u stóp krzyża. Verdi, wielki twórca opery włoskiej, który zbadał i wyraził w swoich operach dramat tak wielu osobowości, opowiada w tym dziele o Maryi Dziewicy, która wpatruje się w ukrzyżowanego Syna. Muzyka staje się tu bardziej istotna, bo „chwyta się" nieomal słów, by wyrazić ów dramat w sposób tak intensywny, jak to tylko możliwe, by wyrazić zwłaszcza pojawiającą się ogromną gamę uczuć. Wystarczy przywołać bolesne odczucie pietà, którym Verdi rozpoczął Sequenza, następnie dramatyczne Pro peccatis suae gentis, szeptane dum emisit spiritus, aż po inwokacje chóralne przepełnione emocjami, ale także pogodne, skierowane do Maryi fons amoris. Wszystko to pozwala uczestniczyć słuchaczom w jej matczynym bólu i zapala ich serca, by płonęły miłością do Chrystusa. A w zwrotce finalnej pojawia się

\footnotetext{
72 Zob. Przemówienie po koncercie ofiarowanym przez prezydenta Republiki Włoskiej Giorgia Napolitana ku czci papieża z okazji 7. rocznicy pontyfikatu, Aula Pawła VI, 11.05.2012.
} 
żarliwa, potężna, skierowana do Boga prośba, aby pozwolił duszy zaznać chwały raju, co jest w istocie ostatecznym pragnieniem wszystkich.

Wykonano również Te Deum Verdiego, które - jak podkreślił Benedykt XVI pełne jest następujących po sobie kontrastów, przy czym kompozytor w sposób skrupulatny i drobiazgowy zwraca tu uwagę na święty tekst, podsuwając niejako inną jego lekturę niż tradycyjna. Bo Verdiemu chodziło nie tyle o zwycięski śpiew koronacyjny, ile - jak sam wyjaśnia - przede wszystkim o następowanie po sobie kolejnych sytuacji: od początkowego uwielbienia - Te Deum, Sanctus, poprzez kontemplację Chrystusa wcielonego, który uwalnia i otwiera Królestwo niebios, inwokację do Iudex venturus, aby miał miłosierdzie, wreszcie po krzyk powtarzanego przez sopran i chór: In te, Domine, speravi, który zamyka dzieło i który jest niemal prośbą Verdiego, by zachować nadzieję i światło na ostatnim etapie życia ${ }^{73}$.

Papież zwrócił też uwagę na to, że te dwa wysłuchane dzieła muzyczne nie były przeznaczone do publikacji, ale że Verdi napisał je jedynie dla siebie; co więcej, chciał być nawet z tymi partyturami Te Deum pochowany. Na koniec dodał jeszcze, że dzieła wielkich kompozytorów muzyki sakralnej zachęcają, by słuchacze zwracali się do Pana Boga z wiarą, powtarzając: „W Tobie, Panie zaufałem, w Tobie z radością pokładam moją nadzieję" i aby modlili się o miłość do Chrystusa, jak Jego święta Matka, aby każdemu przy końcu wędrówki została udzielona chwała nieba.

\subsection{0. Śpiew i muzyka liturgiczna}

Zapewne najważniejszą wypowiedzią, bowiem zawartą w oficjalnym dokumencie papieskim Benedykta XVI na temat śpiewu liturgicznego, jest punkt 41 adhortacji o Eucharystii Sacramentum Caritatis, w którym wskazuje, że źródłem śpiewu - nowej pieśni, nowego człowieka odkupionego przez Chrystusa, który w zebranym Ludzie Bożym na celebracji liturgicznej śpiewa chwałę Boga - jest miłość. Tworzona zaś przez Kościół muzyka i śpiew w ciągu dwutysiącletniej historii stanowią wielkie dziedzictwo wiary i miłości, które należy pieczołowicie pielęgnować.

Oprócz tej urzędowej wypowiedzi są też inne. Otóż papież kilkakrotnie przemawiał do Pueri Cantores, którzy stawiają sobie za cel branie udziału w liturgii Kościoła. Przemawiając do nich po raz pierwszy ${ }^{74}$, zwrócił uwagę, że Sobór Watykański II nie omieszkał przypomnieć, jak bardzo Kościół ceni rolę tych, którzy

73 Zob. G. Verdi, List do Giovanniego Tebaldiniego, 1.03 .1896 r., cyt. za: Przemówienie po koncercie ofiarowanym przez prezydenta Republiki Włoskiej Giorgia Napolitana ku czci papieża z okazji 7. rocznicy pontyfikatu, Aula Pawła VI, 11.05.2012.

${ }^{7}$ Zob. Przemówienie do uczestników Kongresu Międzynarodowego Pueri Cantores, Rzym, 30.12.2005. 
swym śpiewem przyczyniają się do upiększenia liturgii. Bo kiedy Kościół modli się i śpiewa, Chrystus jest rzeczywiście obecny, a lud wierny jednoczy się z Kościołem niebieskim (SC 7-8). Muzyka sakralna ma więc w służbie Bożej swoje szczególne „zadanie służebne”, tj. pomaga ludowi modlić się z godnością i to jest bardzo ważna jej misja (SC 112). Podkreślił zwłaszcza, że kiedy „Kościół modli się, śpiewa lub działa, wiara uczestników wzrasta, a umysły wznoszą się ku Bogu, aby $\mathrm{Mu}$ oddać duchowy hołd i otrzymać obfitszą łaskę" (SC 33).

Kiedy zaś ponownie przyjmował Pueri Cantores z okazji kolejnego ich kongresu w Rzymie, podkreślił, że wznosząc swym śpiewem uwielbienie Boga, wyrażają naturalne pragnienie każdego bytu ludzkiego, by wielbić Go pieśniami miłości, zgodnie z tym, co napisał św. Augustyn, że „Śpiew to wyraz radości i miłości”75. Nieraz trudno znaleźć słowa, które wyrażałyby autentyczną radość spotkania przepełnionego miłością wobec Boga. Dopiero piękna muzyka potrafi wyrazić coś z tajemnicy miłości Boga do nas i naszej miłości do Tego, który jest samą Miłością. Papież uwrażliwiał ich na to, że śpiew jest także służbą: najpierw służbą Bogu, czyli sposobem oddawania Mu chwały, następnie też służbą wiernym, którym ma pomóc wznosić swoje serca i umysły w modlitwie do Boga. Jest wreszcie służbą całemu Kościołowi, aby mógł antycypować liturgię niebiańską, która jest celem całego autentycznego kultu, gdy chóry aniołów i świętych jednoczą się w nieskończonym śpiewie miłości i chwały.

Mowę aniołów spod Betlejem, którą słyszeli pasterze, chrześcijanie zawsze rozumieli jako śpiew i pozwalali, aby inspirował ich do oddawania Bogu czci właśnie przez muzykę i śpiew, a nawet do odnajdywania w tym radości. Śpiew chóralny jest więc szczególną pomocą, jaką chórzyści świadczą wiernym, aby ci ostatni mogli głębiej wniknąć w tajemnice sprawowane podczas liturgii i aby w ten sposób mogli uwielbiać i chwalić Boga, a tym samym ożywiać celebrację liturgiczną. Na koniec papież życzył młodym chórzystom, by ich liturgiczny śpiew, przez który wyrażają wielkość i miłość Boga, pozwolił także im samym wzrastać w świętości. Przy okazji podziękował nauczycielom śpiewu sakralnego za cenną posługę, jaką pełnią w liturgii i zachęcał ich, by w niej nadal trwali, prosząc zarazem, by zawsze pozostawali po prostu uczestnikami życia wspólnot chrześcijańskich, do których należą, a więc nie czuli się niejako wyniesieni ponad te wspólnoty.

Inną okazją do mówienia o muzyce liturgicznej stał się dla papieża koncert ${ }^{76}$ zorganizowany przez włoskie stowarzyszenie św. Cecylii. Przypomniał wówczas, że

75 Przemówienie do uczestników Kongresu Międzynarodowego zorganizowanego przez Międzynarodową Federację Pueri Cantores, Aula Pawła VI, 30.12.2010; Sermones 34,1.

76 Zob. Przemówienie do uczestników spotkania zorganizowanego przez Włoskie Stowarzyszenie Świętej Cecylii, Aula Pawła VI, 10.11.2012. 
konstytucja o liturgii, idąc po linii tradycji Kościoła, uczy, że „święty śpiew związany ze słowami, jest nieodzowną oraz integralną częścią uroczystej liturgii” (SC 112). I dalej wyjaśniał, dlaczego jest on jej częścią konieczną i integralną. Otóż, nie ze względów czysto estetycznych, czyli upiększających w znaczeniu powierzchownym, lecz dlatego, że poprzez swe piękno śpiew współdziała w realizacji zadania, którym jest karmienie wiary i jej wyrażanie. Przyczynia się zatem do uwielbienia Boga i uświęcenia wiernych, co jest podstawowym celem muzyki sakralnej. Dalej zaś papież przekonywał wykonawców, że ich posługa jest także rzeczą niezwykle cenną, ponieważ muzyka, którą wykonują, nie stanowi jedynie dodatku lub tylko zewnętrznego upiększenia liturgii, lecz jest ważnym elementem samej liturgii. Podkreślił więc, że chórzyści swoim śpiewem pomagają całemu zgromadzeniu wielbić Boga i sprawiają, że Jego słowo przenika do głębi serc; że swym śpiewem nie tylko sami się modlą, lecz wyzwalają zarazem modlitwę u innych i w ten sposób uczestniczą poprzez śpiew w modlitwach liturgii, która obejmuje cały Lud Boży, a nawet całe stworzenie wielbiące Boga.

Nie trzeba zatem zbytnio przekonywać, że chóry i muzycy odgrywają wielką rolę w ożywianiu wiary. Dlatego zawsze warto angażować się w udoskonalanie śpiewu liturgicznego, jak też w docenianie i ratowanie wielkiej tradycji muzycznej Kościoła, która - jak stwierdził sam sobór (SC 116) - właśnie w śpiewie gregoriańskim i polifonii osiąga swój najwyższy wyraz. Papież zwrócił też uwagę, że aktywne uczestnictwo całego ludu Bożego w liturgii polega nie tylko na mówieniu, ale jednocześnie na słuchaniu, tj. na przyjmowaniu przez zmysły i ducha słowa Bożego; w tym także na słuchaniu muzyki sakralnej. Ci zatem, którzy mają dar słuchu i wspaniały głos, mogą w czasie sprawowania liturgii rozśpiewać serca wielu osób. Jak podkreślił papież, trzeba zatem robić wszystko, aby muzyka liturgiczna coraz bardziej się udoskonalała, by jak najgodniej wielbiła Boga i świadczyła o tym, że Kościół jest miejscem, w którym, jak w domu, zawsze gości piękno. Od wielu wieków w krajach katolickich muzyka liturgiczna ma przecież wielką, własną tradycję, stanowi ważną część kultury zachodniej i odgrywa znaczącą rolę w odkrywaniu Boga, czy też w ponownym, odnowionym zbliżeniu do orędzia chrześcijańskiego i do misteriów wiary.

Liturgia stawała się nierzadko źródłem wielkiej muzyki zarówno na Wschodzie, jak i na Zachodzie. Okazję do wypowiedzi na temat muzyki Wschodu dał papieżowi występ Rosyjskiej Orkiestry Narodowej i Moskiewskiego Chóru Synodalnego oraz Kapeli Rogów z Petersburga ${ }^{77}$. Podkreślił on wówczas, że pomiędzy muzyką rosyjską i śpiewem liturgicznym istnieje ścisły, pierwotny związek. To bowiem w liturgii i z liturgii zrodziła się i zaczęła rozwijać ogromna część twórczości

77 Zob. Przemówienie po koncercie z okazji Dni Kultury i Duchowości Rosyjskiej w Watykanie pod patronatem Cyryla I, patriarchy Moskwy i całej Rusi, 20.05.2010. 
artystycznej kompozytorów rosyjskich, wydając arcydzieła zasługujące na to, by świat zachodni lepiej je poznał. W wykonanych podczas koncertu utworach ukazał się najgłębszy, najpierwotniejszy duch narodu rosyjskiego, a wraz z nim wiara chrześcijańska, znajdująca niezwykły wyraz w liturgii Bożej i śpiewie liturgicznym, który zawsze jej towarzyszy. Wykonane utwory wielkich rosyjskich artystów XIX i XX wieku (Musorgskiego, Rimskiego-Korsakowa, Czajkowskiego, Rachmaninowa czy metropolity Hilariona) świadczą o tym, że potrafili oni wykorzystać bogatą tradycję rosyjskiej muzyki liturgicznej, czy choćby do niej nawiązywali, jednocześnie czerpiąc niektóre motywy z muzycznych poszukiwań Zachodu nowszych czasów. Dlatego już w samej tej muzyce można odnaleźć zapowiedź, a zarazem urzeczywistnienie spotkania, dialogu, współdziałania Zachodu ze Wschodem, a także połączenia tradycji z nowoczesnością. Benedykt XVI przypomniał przy tej okazji, że „Taką właśnie wizję harmonijnej jedności Europy miał na myśli Jan Paweł II, kiedy nawiązując do myśli Wieczysława Iwanowa, mówił o «dwóch płucach», którymi powinna oddychać na nowo Europa i wzywał do uświadomienia sobie na nowo głębokich i wspólnych korzeni kulturowych i religijnych kontynentu europejskiego, bez których dzisiejsza Europa byłaby niejako pozbawiona duszy, a w każdym razie jej obraz bytby ograniczony".

\subsection{Muzyka organowa}

Ceremonia pobłogosławienia nowych organów w bazylice Najświętszej Maryi Panny ze Starej Kaplicy w Ratyzbonie i uroczyste przeznaczenie ich do celu, jakim jest uwielbienie Boga i budowanie wiary wiernych ${ }^{78}$ dały z kolei papieżowi okazję - w czasie jego podróży do Bawarii - do wypowiedzi na temat muzyki organowej. Stwierdził wówczas, że organy uważa się zawsze i słusznie za królową instrumentów muzycznych, ponieważ gromadzą one wszystkie dźwięki, jakie wydają stworzenia, pozwalają też w pełni wybrzmieć wszelkim ludzkim uczuciom: od radości do smutku, od uwielbienia i oddawania chwały, aż po lament duszy. Co więcej, wykraczając, jak każda muzyka wysokiej klasy, ponad sferę ludzkiego doświadczenia, odsyłają do tego, co Boskie. Wielka różnorodność dźwięków, od cichego aż po najmocniejsze, które wydają się zdolne zburzyć najpotężniejsze mury, czyni z organów narzędzie przewyższające wszystkie inne instrumenty. Organy są bowiem w stanie wyrazić właściwie wszystko, co zawiera doświadczenie ludzkiej egzystencji. I - jak zauważył - te wielorakie możliwości organów do pewnego stopnia przypominają nieskończoność i wspaniałość Boga.

\footnotetext{
78 Zob. Przemówienie z okazji pobłogosławienia nowych organów w bazylice Najświętszej Maryi Panny ze Starej Kaplicy w Ratyzbonie, 13.09.2006.
} 
Aby zaprezentować możliwości nowych organów, wykonano Psalm 150, w którym jest mowa o trąbkach i fletach, harfie i cytrach, cymbałach i kotłach. Psalmista wzywa bowiem te wszystkie instrumenty muzyczne, by wniosły swój wkład w uwielbianie Boga. W organach wszystkie piszczałki i registry muszą być ze sobą dobrze zgrane. Jeśli któreś z nich się blokuje, jeśli choć jedna piszczałka fałszuje, nie pozostając $\mathrm{w}$ harmonii z innymi, to początkowo uchwytuje tę dysharmonię jedynie ucho kogoś bardzo doświadczonego muzycznie. Ale jeśli już kolejne piszczałki zaczynają fałszować, dochodzi do takiej dysharmonii, która staje się nie do zniesienia. Piszczałki organowe narażone są także na zmiany temperatury i na zmęczenie. To wszystko może przypominać również obraz wspólnoty Kościoła. I podobnie, jak w przypadku organów, doświadczona ręka musi wciąż na nowo doprowadzać dysharmonię do właściwego brzmienia, tak też i w Kościele, który jest różnorodnością darów i charyzmatów, konieczne jest świadome budowanie zgody, by uwielbienie Boga dokonywało się w komunii i by w jedności była realizowana miłość braterska. O ile wierni, poprzez udział w liturgii, coraz bardziej upodabniają się do Chrystusa, o tyle promieniując potem dobrocią, miłosierdziem i miłością wobec ludzi, okazują się też coraz bardziej zdolni do rzeczywistej przemiany świata.

Papież wspomniał jednocześnie o doniosłości tego miejsca. Otóż tworzący, działający tam Carl Joseph Proske w XIX wieku przyczynił się w sposób istotny do odnowy muzyki sakralnej. Dzięki niemu bowiem śpiew gregoriański i starożytna, klasyczna polifonia głosowa zostały w sposób integralny włączone w sam przebieg liturgii. Troska o muzykę liturgiczną „Starej Kaplicy” była tak silna, że zaczęła ona promieniować nawet poza granice regionu i uczyniła z Ratyzbony centrum ruchu zmierzającego do reformy muzyki sakralnej. Jej wpływ dotrwał nawet do czasów współczesnych. W związku z tym Benedykt XVI przypomniał, że w soborowej konstytucji o liturgii wyakcentowano, iż „święty śpiew połączony ze słowami, jest częścią konieczną i integralną uroczystej liturgii” (SC 112). I kolejny raz podkreślił, że oznacza to, iż muzyka i śpiew są czymś więcej, niż tylko upiększeniem kultu; że stanowią część sprawowanej liturgii, że są po prostu samą liturgią. Tak więc uroczysta muzyka sakralna wraz z chórem, organami, orkiestrą i śpiewem ludu nigdy nie powinny być jedynie dodatkiem, który stanowiłby zwykłe obramowanie czy uprzyjemnienie liturgii, ale zawsze pozostają ważnym sposobem aktywnego uczestnictwa w wydarzeniu kultowym.

Papież przypomniał ostatecznie, że wielcy kompozytorzy zawsze poprzez swą muzykę chcieli na swój sposób wielbić Boga. Na przykład Bach umieszczał zwykle pod tytułem swoich partytur litery: S.D.G. - „Soli Deo gloria” („Jedynemu Bogu chwała”). Także Bruckner stawiał na początku słowa: „Dedykowane dobremu Bogu". Stąd papież życzył, by nawiedzających bazylikę doprowadzała do wiary 
nie tylko wspaniałość budowli, ale i liturgia ubogacona grą nowych organów oraz uroczystym śpiewem.

\section{Podsumowanie}

Z przedstawionych w artykule przemówień Benedykta XVI z okazji ofiarowanych mu ponad 40 koncertów wielkiej muzyki oraz przemówień przy innych okolicznościach wyłania się obraz papieża jako wielkiego znawcy muzyki światowej oraz muzyki sakralnej. W swych komentarzach przedstawiał kontekst, w jakim powstało wykonane przez orkiestrę czy chór dzieło, intencje, jakimi kierował się kompozytor, jakie myśli zawarł i jakim dyskursem muzycznym je wyrażał. Widać też jego wielką wrażliwość na wykonywaną muzykę - potrafił dostrzec, co zamierzał wyrazić dyrygent z orkiestrą i chórem, umiał docenić mistrzowskie oryginalne wykonanie. Potrafił też przeżywać tę muzykę; ona była w stanie poruszyć jego emocje, przeniknąć do serca i poruszyć ducha. Dzięki temu muzyka ożywiała jego codzienność, nadając świąteczny i wzniosły charakter dniu powszedniemu.

W komentarzach i wypowiedziach muzykologicznych papieża wybijają się dwie podstawowe cechy muzyki i śpiewu: charakter uniwersalny oraz charakter teologalny. Uniwersalny, ponieważ muzyka nie jest - jak mówił - jakimś przypadkowym połączeniem dźwięków, lecz posiada piękno, głębię, przesłanie, które odsyła słuchacza poza teraźniejszość, poza materialność, podnosi ducha ku sprawom nieprzemijającym, ponadczasowym, ponadnarodowym, ponadkulturowym. Te aspekty starano się wydobyć z papieskich przemówień w pierwszej części artykułu. A więc w ramach wymiaru powszechnego został podkreślony aspekt egzystencjalny, humanizujący i edukacyjny.

Jednak to zorientowanie muzyki i śpiewu ku temu, co uniwersalne, nie jest u Benedykta XVI ukierunkowaniem ku jakiemuś abstrakcjonizmowi, jakiejś pustce egzystencjalnej, lecz jest ukierunkowaniem teologalnym, tzn. ku Prawdzie, Dobru, Pięknu osobowemu, ku Komuś Transcendentnemu, Komuś dalekiemu, ku Stwórcy piękna kosmosu, ale i piękna artystycznego, w tym muzycznego, Dawcy talentów tworzących piękno, a równocześnie ku Bogu bliskiemu, Bogu-Człowiekowi, Chrystusowi, który objawił się jako Miłość osobowa. Muzyka i śpiew umożliwiają poszukiwanie Boga i zarazem kontemplację tajemnic Jego istnienia i działania zbawczego. W przekonaniu papieża nie da się oddzielić wymiaru uniwersalnego od teologalnego; w jego nauczaniu nawzajem się przenikają.

Ważnym elementem nauki papieża o muzyce i śpiewie jest uświadomienie odbiorcom ewangelicznych korzeni oraz chrześcijańskiego charakteru cywilizacji zachodniej. Spotkanie z Bogiem Miłością było w całej historii Europy Zachodniej źródłem tworzenia muzyki i śpiewu: miłość do Boga i wola Jego uwielbienia były 
spiritus movens wielkich dzieł muzycznych, którymi szczyci się Europa Zachodnia. $\mathrm{Na}$ tych zagadnieniach skupiono się w drugiej części artykułu, gdzie w oparciu o konkretne utwory wskazano te korzenie. Przedstawiono też Benedyktowy opis istoty muzyki kościelnej, drogi piękna do Boga, roli muzyki i śpiewu w nawróceniu i umocnieniu wiary, w uwydatnieniu wydarzeń zbawczych, w wyrażaniu miłości do stworzeń i Stwórcy, w potęgowaniu żaru modlitwy, omówiono znaczenie muzyki sakralnej, śpiewu liturgicznego i zakończono omówieniem muzyki organowej - jako ukoronowania muzyki wszystkich instrumentów. A zatem w artykule niniejszym starano się przedstawić całościowo zagadnienia muzykologiczne poruszane w przemówieniach papieskich, dając w ten sposób obraz bogaty i usystematyzowany.

\begin{abstract}
Abstrakt
Niniejszy artykuł został napisany głównie w oparciu o liczne przemówienia Benedykta XVI z okazji ofiarowanych mu koncertów wielkiej muzyki światowej. Wyłania się z nich obraz papieża jako wielkiego miłośnika i znawcy tej dziedziny. W jego komentarzach i wypowiedziach muzykologicznych wybijają się dwie podstawowe cechy muzyki i śpiewu: charakter uniwersalny oraz charakter teologalny. Uniwersalny, ponieważ odsyła słuchacza ku sprawom nieprzemijającym, ponadnarodowym, ponadkulturowym. Te aspekty starano się wydobyć z papieskich przemówień w pierwszej części artykułu. Jednak to zorientowanie muzyki i śpiewu ku temu, co uniwersalne, nie jest u Benedykta XVI ukierunkowaniem ku jakiemuś czystemu abstrakcjonizmowi, jakiejś pustce egzystencjalnej, lecz jest ukierunkowaniem teologalnym, tzn. ku Stwórcy piękna kosmosu, ale i piękna artystycznego, w tym muzycznego, Dawcy talentów tworzących piękno, a równocześnie ku Bogu-Człowiekowi, który objawił się jako Miłość osobowa. Muzyka i śpiew umożliwiają poszukiwanie Boga i zarazem kontemplację tajemnic Jego istnienia i działania zbawczego. W przekonaniu papieża nie da się oddzielić wymiaru uniwersalnego od teologalnego; w jego nauczaniu nawzajem się przenikają.
\end{abstract}

Stowa kluczowe: Benedykt XVI; muzyka i śpiew; uniwersalny i teologalny; sakralny; liturgiczny; via pulchritudinis; chrześcijańska kultura europejska 


\section{Abstract \\ Universal and Theological Character of the instrumental and vocal Music in the Teaching of Benedict XVI}

This article was written mainly on the basis of numerous pope's Benedict XVI speeches given on the occasion of over 40 of the great world music concerts offered to him. From them emerges an image of the pope as a great lover and expert in this field. In his comments he had presented the context in which the work performed by the orchestra or choir was created, the composer's intentions, what thoughts he contained and by what musical discourse he expressed them. One can also see his great sensitivity to the performed music, he was able to see what the conductor with the orchestra and choir intended to express and he was able to appreciate the masterly original performance. He could also experience this music; it was able to move his emotions, penetrate his heart and move his spirit. Thanks to this, music was reviving his everyday life and giving to it a festive and sublime character.

In the musicological comments and statements of the pope, two basic features of music and singing stand out: universal character and theological character. Universal, because music is not - as he said - an accidental combination of sounds, but has a beauty, depth, message that sends the listener above the present, above materiality, raises up the spirit to matters of everlasting, timeless, supranational, supracultural. And these aspects were tried to be extracted from the papal speeches in the first part of the article.

However, this orientation of music and singing towards the universal is not Benedict's XVI orientation towards some pure abstractionism, towards some existential emptiness, but it is theologically oriented, i.e. towards Truth, Goodness, Personal Beauty, towards Someone Transcendent, Someone distant, towards the Creator of the beauty of the cosmos, but also artistic beauty, including music, towards the Giver of the talents who create beauty, and at the same time towards God who is close, God-Man, Christ, who revealed himself as Personal Love. Music and singing make possible search for God and at the same time contemplation of the mysteries of his existence and saving action. According to the pope's idea, the universal and theological dimensions cannot be separated; in his teaching they interpenetrate each other.

An important element of the pope's teaching about music and singing is to make the recipients aware of the evangelical roots and the Christian nature of the Western civilization. The meeting with God - Love was throughout the history of the Western Europe a source of music and singing: love for God and the will to worship him were the spiritus movens of the great musical works in which the Western Europe boasts. These issues are focused in the second part of this article, where based on the specific works are pointed these roots. There is also presented Benedict's description of the essence of the Church music, the path of beauty to God, the role of music and singing in conversion and strengthening the faith 
in emphasizing of the salvific events, in expressing love for the creatures and the Creator, in intensifying the zeal of prayer. Besides, there is presented the importance of the sacred music and liturgical singing and at the end the organ music - as the crowning achievement of the music of all instruments. Thus, this article attempts to present holistically the musicological issues raised in the papal speeches, giving generally a rich and systematized image.

Keywords: Benedict XVI; music; singing; universal; theological; sacral; liturgical; via pulchritudinis; Chrisitian European Culture

\section{Bibliografia}

\section{Źródta}

Benedykt XVI, Posynodalna adhortacja apostolska Sacramentum Caritatis, 22.02.2007. Benedykt XVI, Przemówienia, http://www.vatican.va/content/benedict-xvi/it.html (20.06.2020):

20.10.2005. Przemówienie na zakończenie koncertu wykonanego ku czci Benedykta XVI przez orkiestrę Filharmonii z Monachium w Bawarii, Aula Pawła VI.

22.10.2005. Przemówienie na zakończenie koncertu wykonanego ku czci papieża przez Regensburger Domspatzen - chór katedry w Ratyzbonie, Kaplica Sykstyńska.

30.12.2005. Przemówienie do uczestników Kongresu Międzynarodowego Pueri Cantores, Rzym.

13.09.2006. Przemówienie z okazji pobłogosławienia nowych organów w bazylice Najświętszej Maryi Panny ze Starej Kaplicy w Ratyzbonie.

18.11.2006. Przemówienie po koncercie ku czci papieża ofiarowanym przez prezydenta Republiki Federalnej Niemiec.

16.04.2007. Przemówienie po koncercie Orkiestry Symfonicznej Radia i Telewizji w Stuttgarcie ku czci papieża z okazji jego 80. urodzin, Aula Pawła VI.

23.05.2007. Przemówienie z okazji wykonania oratorium ofiarowanego przez Konferencję Episkopatu Włoch z okazji 80. urodzin Benedykta XVI.

4.09.2007. Przemówienie po koncercie z okazji obchodów tysiąclecia archidiecezji Bamberg, Castel Gandolfo.

20.07.2007. Przemówienie po koncercie chórów góralskich ofiarowanym przez diecezję Belluno-Feltre, Lorenzago di Cadore.

26.09.2007. Przemówienie z okazji 110. rocznicy urodziny papieża Pawła VI, Castel Gandolfo.

28.09.2007. Przemówienie do delegacji Wyższej Szkoły Katolickiej Muzyki Kościelnej w Ratyzbonie, Castel Gandolfo. 
13.10.2007. Przemówienie w czasie wizyty w Papieskim Instytucie Muzyki Świętej w Rzymie.

27.10.2007. Przemówienie po koncercie Orkiestry Symfonicznej i Chóru Radia Bawarskiego, Aula Pawła VI, „L’Osservatore Romano” (wydanie polskie) 12 (2007), s. 21-22.

24.04.2008. Przemówienie po koncercie ofiarowanym przez prezydenta Republiki Włoskiej Giorgia Napolitana ku czci papieża z okazji 3. rocznicy jego pontyfikatu.

7.05.2008. Przemówienie na zakończenie koncertu ofiarowanego i wykonanego przez Orkiestrę Filharmonii Chińskiej i przez Chór Opery Shanghai, Aula Pawła VI.

21.05.2008. Katecheza w czasie audiencji generalnej, Roman Pieśniarz, Aula Pawła VI.

24.08.2008. Przemówienie po koncercie wykonanym ku czci papieża, Castel Gandolfo.

12.09.2008. Przemówienie do przedstawicieli świata kultury, Paryż, Collegium Bernardinum.

13.10.2008. Przemówienie po koncercie ofiarowanym przez Fundację Muzyki i Sztuki Sakralnej, wykonanym przez Wiener Philharmoniker z okazji Synodu biskupów, bazylika św. Pawła za Murami.

10.12.2008. Przemówienie po koncercie zorganizowanym przez Papieską Radę Iustitia et Pax, w 60. rocznicę uchwalenia Powszechnej Deklaracji Praw Człowieka. 30.04.2009. Przemówienie po koncercie ofiarowanym przez prezydenta Republiki Włoskiej Giorgia Napolitana z okazji 4. rocznicy pontyfikatu papieża.

2.08.2009. Przemówienie po koncercie ku czci papieża ofiarowanym przez Bayerisches Kammerorchester Bad Brücknau, Castel Gandolfo.

8.10.2009. Przemówienie po koncercie Giovanni contro la guerra organizacji Interregionales Jugendsinfonieorchester (IRO) w 70. rocznicę rozpoczęcia drugiej wojny światowej.

21.11.2009. Przemówienie na spotkaniu z artystami, Kaplica Sykstyńska.

4.12.2009. Przemówienie po koncercie ku czci papieża ofiarowanym przez prezydenta Republiki Federalnej Niemiec z okazji 60. rocznicy ustanowienia Republiki Federalnej Niemiec i 20. rocznicy upadku muru berlińskiego, Kaplica Sykstyńska.

20.05.2010. Przemówienie po koncercie z okazji Dni Kultury i Duchowości Rosyjskiej w Watykanie pod patronatem Cyryla I, patriarchy Moskwy i całej Rusi. 7.09.2010. Przemówienie po koncercie na dziedzińcu Pałacu Apostolskiego w Castel Gandolfo, „L'Osservatore Romano” (wydanie polskie) 10 (2010), s. 25.

1.10.2010. Przemówienie po koncercie na zakończenie prac restauracyjnych przy bazylice watykańskiej ofiarowanym przez organizację ENI, Aula Pawła VI. 
16.10.2010. Przemówienie po koncercie ku czci papieża ofiarowanym przez maestro Enocha zu Guttenberga, Aula Pawła VI.

30.12.2010. Przemówienie do uczestników Kongresu Międzynarodowego zorganizowanego przez Międzynarodową Federację Pueri Cantores, Aula Pawła VI.

5.05.2011. Przemówienie po koncercie Opery Rzymskiej ofiarowanym przez prezydenta Włoch z okazji 6. rocznicy pontyfikatu, Aula Pawła VI, „L’Osservatore Romano” (wydanie polskie) 7 (2011), s. 21-22.

27.05.2011. Przemówienie po koncercie ofiarowanym przez prezydenta Republiki Węgier Pála Schmitta z okazji węgierskiej prezydencji w Radzie Unii Europejskiej oraz w 200. rocznicę urodzin Ferenca Liszta, Aula Pawła VI.

9.08.2011. Przemówienie po koncercie ofiarowanym przez Ensemble „New Seasons” ku czci papieża i brata, prałata Georga Ratzingera, z okazji 60. rocznicy kapłaństwa.

31.08.2011. Katecheza w czasie audiencji generalnej, Castel Gandolfo.

31.08.2011. Przemówienie z okazji koncertu ofiarowanego przez kard. Domenica Bartolucciego, Castel Gandolfo.

22.10.2011. Przemówienie po koncercie ofiarowanym przez Bayerische Staatsoper, Aula Pawła VI.

20.04.2012. Przemówienie po koncercie ofiarowanym przez orkiestrę Gewandhaus z Lipska z okazji 85. urodzin Ojca świętego, Aula Pawła VI.

11.05.2012. Przemówienie po koncercie ofiarowanym przez prezydenta Republiki Włoskiej Giorgia Napolitana ku czci papieża z okazji 7. rocznicy pontyfikatu, Aula Pawła VI.

11.07.2012. Przemówienie po koncercie ofiarowanym przez West-Eastern Divan Orkiestra, Castel Gandolfo.

3.08.2012. Przemówienie po koncercie Serata Bavarese ku czci papieża, wykonanym w ramach pielgrzymki archidiecezji Monachium i Freising do Rzymu, Castel Gandolfo.

11.08.2012. Przemówienie po koncercie ofiarowanym przez Caritas z Regensburga, Castel Gandolfo.

26.09.2012. Przemówienie po wykonaniu oratorium Augustinus - un mosaico di suoni ofiarowanego przez diecezję Würzburg, Castel Gandolfo.

31.10.2012. Przemówienie w czasie pierwszych nieszporów z okazji 500. rocznicy odsłonięcia malowideł w Kaplicy Sykstyńskiej.

10.11.2012. Przemówienie do uczestników spotkania zorganizowanego przez Włoskie Stowarzyszenie Świętej Cecylii, Aula Pawła VI.

4.02.2013. Przemówienie po koncercie ofiarowanym przez ambasadę Włoch przy Stolicy Świętej ku czci papieża i prezydenta Republiki Włoskiej Giorgia Napolitana z okazji 84. rocznicy traktatów laterańskich, Aula Pawła VI. 
Sobór Watykański II, Konstytucje. Dekrety. Deklaracje, Poznań 2002.

\section{Opracowania}

Bramorski J., Teologiczno-estetyczne wyznaczniki sakralności dzieta muzycznego, „Pro Musica Sacra” 11 (2013), s. 11-22.

Kurnik K., Muzyka czy „pioseneczki tatwe i modne”? Spojrzenie na muzyczna sztukę w liturgii w oparciu o wybrane wypowiedzi Josepha Ratzingera - Benedykta XVI, „Pro Musica Sacra” 13 (2015), s. 71-84.

Linneborn M., Odnowione pojmowanie roli chórów w liturgii, „Pro Musica Sacra” 16 (2018), s. 101-112.

Samulnik T., Biblijne i systematyczne źródta teologii muzyki Josepha RatzingeralBenedykta XVI, „Pro Musica Sacra” 16 (2018), s. 127-142.

Tyrała R., Muzyka liturgiczna w przeżyciu Misterium Paschalnego, „Pro Musica Sacra” 12 (2014), s. 9-23.

Tyrała R., Benedykt XVI doktorem honoris causa Akademii Muzycznej i Uniwersytetu Papieskiego Jana Pawta II w Krakowie, „Pro Musica Sacra” 13 (2015), s. 9-37.

Ziemlewski M., Góreckiego „Beatus Vir” wobec nauczania Josepha kard. Ratzingera (Jezus z Nazaretu). Teologiczna interpretacja, „Pro Musica Sacra” 16 (2018), s. 143-153. 